\title{
REVIEW
}

\section{Chromatin reprogramming in breast cancer}

\author{
Erin E Swinstead1,*, Ville Paakinaho',2,* and Gordon L Hager ${ }^{1}$ \\ 'Laboratory of Receptor Biology and Gene Expression, National Cancer Institute, NIH, Bethesda, Maryland, USA \\ Institute of Biomedicine, University of Eastern Finland, Kuopio, Finland \\ Correspondence should be addressed to G L Hager: hagerg@exchange.nih.gov \\ *(E E Swinstead and V Paakinaho contributed equally to this work)
}

\begin{abstract}
Reprogramming of the chromatin landscape is a critical component to the transcriptional response in breast cancer. Effects of sex hormones such as estrogens and progesterone have been well described to have a critical impact on breast cancer proliferation.

However, the complex network of the chromatin landscape, enhancer regions and mode of function of steroid receptors (SRs) and other transcription factors (TFs), is an intricate web of signaling and functional processes that is still largely misunderstood at the mechanistic level. In this review, we describe what is currently known about the dynamic interplay between TFs with chromatin and the reprogramming of enhancer elements. Emphasis has been placed on characterizing the different modes of action of TFs in regulating enhancer activity, specifically, how different SRs target enhancer regions to reprogram chromatin in breast cancer cells. In addition, we discuss current techniques employed to study enhancer function at a genome-wide level. Further, we have noted recent advances in live cell imaging technology. These single-cell approaches enable the coupling of population-based assays with real-time studies to address many unsolved questions about SRs and chromatin dynamics in breast cancer.
\end{abstract}

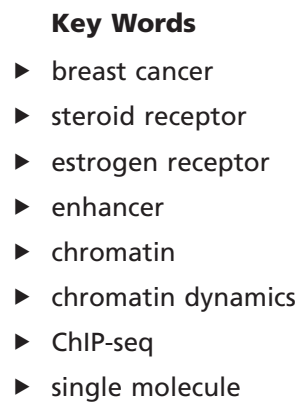

Endocrine-Related Cancer (2018) 25, R385-R404

\section{Introduction}

Transcriptional regulation is one of the most important biological processes in organisms, contributing to every aspect of health and disease. The regulation of gene expression is a complex process involving a multitude of proteins, including transcription factors (TFs), cofactors and RNA polymerases. These proteins bind and interact with specific regulatory elements termed enhancers on chromatin. Here, the transcriptional regulation activity is influenced through a number of different processes (Voss \& Hager 2014, Long et al. 2016). The enhancer landscape and the accessibility of chromatin at enhancers are constantly changing during cellular development and differentiation (Chronis et al. 2017). Interestingly, the enhancer landscape in all developed cells appears to represent subsets of a general population of enhancers identified in embryonic stem cells (Stergachis et al. 2013). In many cases, TFs reprogram the chromatin landscape by altering the chromatin accessibility, thereby influencing the activity and recruitment of other TFs, cofactors and RNA polymerases. The cofactors recruited by TFs can possess a variety of enzymatic properties, such as histone-modifying and ATP-dependent chromatinremodeling activities. These events have a crucial role in regulating chromatin accessibility (Perissi \& Rosenfeld 2005, Long et al. 2016, Murakami et al. 2017, Yi et al. 2017). Reprogramming ensures accurate regulatory TF binding and subsequent regulation of cell-type specificity. Abnormal alterations in the activity of TFs can aberrantly 
program the chromatin landscape leading to many different disease states (Smith \& Shilatifard 2014). The most drastic examples of abnormal alterations of TF binding and chromatin accessibility occurs in cancers (Denny et al. 2016, Qu et al. 2017). Breast cancer is no exception, with alterations occurring in chromatin accessibility, TF action and regulation (Jeselsohn et al. 2015, D'Antonio et al. 2017, Rheinbay et al. 2017, Toy et al. 2017). Furthermore, the development of mammary epithelial cells to breast carcinoma can create novel enhancers unique to the progression of this cancer subtype (Stergachis et al. 2013). It has been shown that deletion of single-nucleotide polymorphisms (SNPs) containing the enhancer that upregulates MYC in intestinal cancer results in the decrease of MYC expression and resistance to tumorigenesis (Sur et al. 2012). This highlights the importance of enhancers in cancers (Sur \& Taipale 2016). Furthermore, this mechanism is not exclusive to cancer, as SNPs at nuclear receptor regulatory regions can influence metabolic disease risk and subsequent effectiveness of therapeutics (Soccio et al. 2015). In addition to SNPs, a large number of genomic alterations and mutation occur in cancers (Beroukhim et al. 2010, Bignell et al. 2010, Rheinbay et al. 2017). For example, a mutational hotspot at the FoxA1 promoter region leads to increased protein expression that can influence the action of other TFs in breast cancer (Rheinbay et al. 2017). In addition, FoxA1 can drive enhancer reprogramming during development of pancreatic cancer (Roe et al. 2017). In the last year, it has also been recognized that not only direct DNAbinding TFs, but also recruited cofactors can drive chromatin reprogramming. This has prominently been described with chromatin remodeling complexes whose action can drastically change the chromatin landscape in various cancers (Pulice \& Kadoch 2016, Boulay et al. 2017, Kadoch et al. 2017). In addition, many other cofactors, such as histone modification writers, readers and erasers are misregulated in cancers (Kim \& Roberts 2016, Lonard \& O'Malley 2016, Dawson 2017). Due to these observations, there is a growing interest to develop therapeutics targeting cofactors rather than TFs (Illendula et al. 2015, Song et al. 2016, Bennett \& Licht 2017, Lasko et al. 2017, Ribich et al. 2017).

The discovery and history of nuclear receptors, including SRs, has been extensively reviewed by others (Mangelsdorf et al. 1995, Chawla et al. 2001, Lazar 2017). Here, we will focus on the reprogramming of the breast cancer chromatin landscape through steroid receptors (SRs). As the female sex hormone estrogen plays a predominate role in breast cancer growth, emphasis will be placed on the estrogen receptor (ER) and its cooperative action with other TFs. Furthermore, we will review the current knowledge of how TFs bind and interact with chromatin to reprogram the chromatin landscape.

\section{Breast cancer}

Breast cancer is the leading cause of cancer-related death in women. One in eight women will develop the disease in their lifetime in the United States alone. In addition, there will be 230,000 new cases diagnosed and approximately 40,000 women succumbing to the disease each year (Siegel et al. 2011). The epithelial cells that line the lobules or ducts are the predominant site for breast cancer initiation. These first detectable lesions are neoplastic growths confined within individual ducts, considered pre-invasive and termed in situ carcinoma. Invasive carcinoma is the next stage in breast cancer development. Here, the cells breach the basement membrane and invade the surrounding breast stromal tissue (Roses 1999). The last stage in the progression of the disease is metastasis of the invasive cells. During this stage, the cells can migrate from the primary tumor site, via the blood stream or lymphatic system, where they transplant into the lymph nodes or other organs. It is well documented that $17 \beta$-estradiol (E2), an active metabolite of estrogen, is required for the development, growth and homeostatic maintenance of normal and malignant breast tissue. Historically, it has been determined that the removal of the ovaries suppressed the growth of breast cancer (Beatson 1896, Wittliff 1984, Mauvais-Jarvis et al. 1990). This was first reported in 1896, when a bilateral oophorectomy was performed in a premenopausal patient, resulting in a complete remission of the disease (Beatson 1896). Many years later, the ER was discovered (Jensen \& DeSombre 1973) and the association to the removal of the ovaries and tumor remission could be attributed to the dependence of E2 on breast cancer growth. This discovery was quickly followed by the first cloning of ER (Walter et al. 1985) and then isolation of a complementary DNA clone from translated mRNA of ER. This isolation was from the MCF-7 human breast cancer cells, which manifest functional expression of the protein (Greene et al. 1986).

The SRs that mediate the effects of steroid hormones, such as E2, are involved in the progression and prognosis of hormone associated cancers. The ER is expressed in approximately $50-88 \%$ of all breast cancers, with the progesterone receptor (PR) expressed in 45-82\% (McGuire 1978, Rosa et al. 2008). Primary diagnosis of breast cancer 
is subtyped by ER, PR and the human epidermal growth factor 2 (HER2) expression to determine the current treatment approaches. Given the known role of ER in breast cancer development, it is primarily utilized as a therapeutic target in the clinic. PR is a well-described E2-regulated gene, and its dependence on ER signaling is utilized solely as a marker of a functional ER (Creighton et al. 2009). At present, the standard of care for patients with ER-positive breast cancers is to inhibit the receptors functionality. This is achieved by active competition of ER with antagonists such as tamoxifen. Alternatively, the use of aromatase inhibitors results in ER signaling inhibition by blocking the catalytic processes of estrogen production (Arpino et al. 2009). Generally, these treatments are effective short term; however, $30-50 \%$ of ER-positive tumors display resistance to these therapies and generally all metastatic ER-positive breast cancers acquire resistance (Mouridsen et al. 2003, Arpino et al. 2009). Two major trials, the Women's Health Initiative (WHI) and the Million Women Study, investigated the effects of estrogen and progestin on breast cancer incidence. Both studies looked at the use of hormone replacement therapy (HRT) (i.e. estrogen only) and combined hormone replacement therapy (cHRT) (i.e. estrogen and progestin in combination). The WHI concluded that women on cHRT had an increased risk of invasive breast cancer compared to placebo-treated women, with an incidence of 0.38 and $0.3 \%$, respectively (Rossouw et al. 2002). Similar findings were found in the Million Women Study, concluding that women on HRT or cHRT were at a higher risk of developing breast cancer compared to women that had not used, or were not currently using either of these therapies (Beral 2003). However, these results have remained controversial over the years. Recently, there has been the suggestion that HRT may have no effect on breast cancer incidence in younger women and could provide a level of protection in older women (Santen 2014). The level of proposed protection in older women has been suggested to be a result of estrogen-induced apoptosis in breast tumors (Santen 2014, Jordan 2015). This finding contrasts historic and current data and is an avenue of importance that needs to be further explored.

For the SR family, the androgen receptor (AR) and the glucocorticoid receptor (GR) each have a multitude of functions in human biology and disease progression. In addition to ER and PR, AR and GR have also been implicated in breast cancer progression. Specifically, AR is found to be expressed in up to $85 \%$ of primary breast tumors (Honma et al. 2012, Qi et al. 2012). Tumors expressing
AR/ER/PR present with a better prognosis (Garreau et al. 2006) compared to AR-positive ER/PR-negative tumors (Lin Fde et al. 2012). Further, the patients with AR/ER/PR-positive tumors have smaller tumor size, lower Ki-67 expression (marker of proliferation) and better disease-free survival compared to AR-negative ER/PR-positive tumor patients (Hu et al. 2011, Qi et al. 2012). More recently, the role of GR in mediating breast cancer development has begun to emerge. It appears the effect of GR on breast cancer is dependent on the expression of ER. Specifically, there has been an association with chemoresistance and a short disease-free survival period in triple-negative breast cancer (breast cancer that lacks expression of ER, PR and HER2 growth factor) (Pan et al. 2011). However, cancers that express ER, PR and have high GR expression, demonstrate an increased overall disease-free survival (Pan et al. 2011). It is important to note that the overall levels of circulating endogenous ligand of the SRs change throughout the female monthly menstrual cycle. In addition, levels of estrogen are markedly decreased once a female goes through menopause. It is becoming clear that the role of SR signaling in breast cancer progression is complex and likely involves a crosstalk between multiple TFs. To fully understand the complexity behind these SR signaling pathways, we need to increase our knowledge of the genetic elements that they bind, and the modes of action by which ER, PR, AR and GR collaborate at these enhancer elements. Advances in our understanding of the genomic responses of these factors will undoubtedly lead to improved patient therapies.

\section{Techniques used to study chromatin dynamics}

The chromatin landscape predominately defines the genomic response of TFs, with the accessibility of enhancer elements affecting the gene transcription response of a given stimulus. Enhancers serve as the critical regulatory elements of the cells; characterization of their functional activity states can be achieved by multiple populationbased assays (Fig. 1). In the last 10 years, these techniques have become available to almost all scientists (Soon et al. 2013). These methods can be used to characterize a wide range of chromatin landscape properties including chromatin accessibility, nucleosome mapping, TF occupancy and long-range chromatin conformations (Maston et al. 2012). For transcriptional regulation of an enhancer region, the chromatin landscape must be accessible to the TF attempting to elucidate its response. 


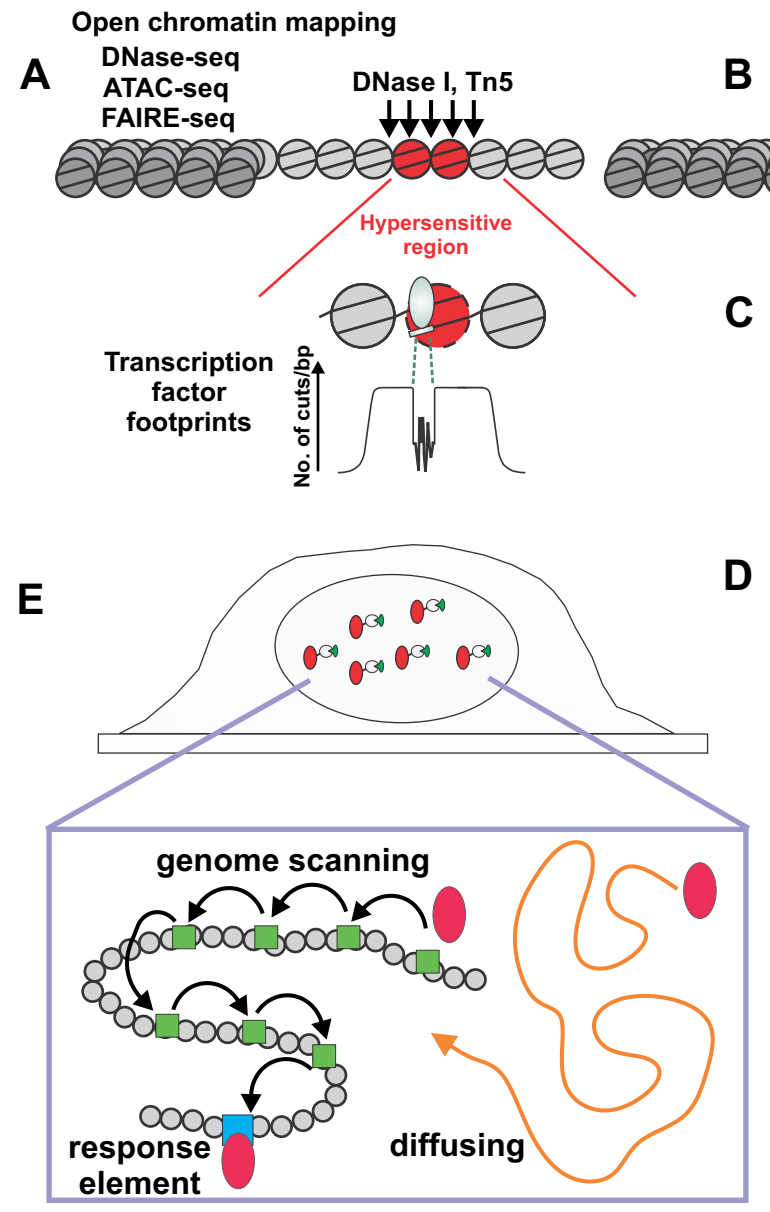

$\mathbf{F}$

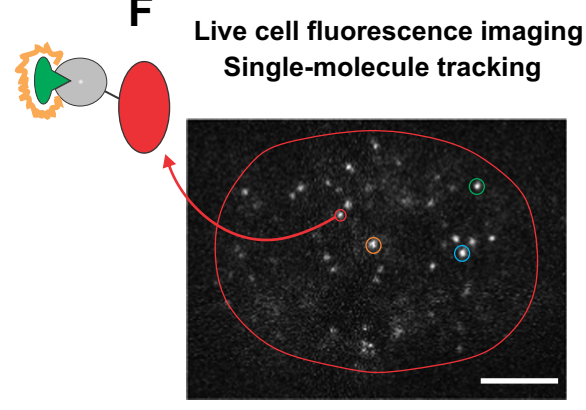

Nucleosome mapping

MNase-seq MNase

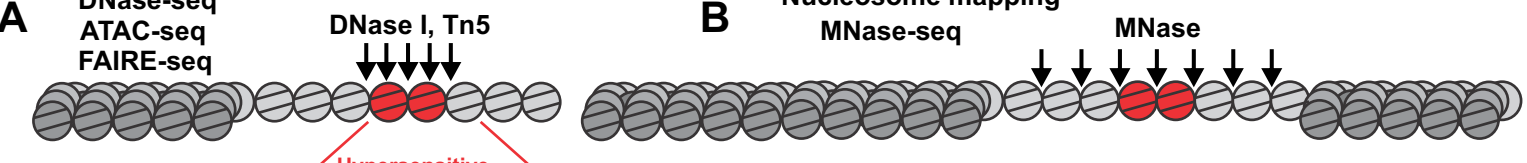

Transcription factor and modification mapping

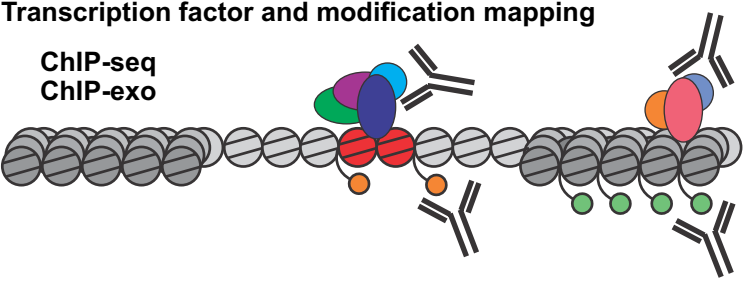

D Chromatin conformation mapping

3C, 4C, 5C, Hi-C ChIA-PET
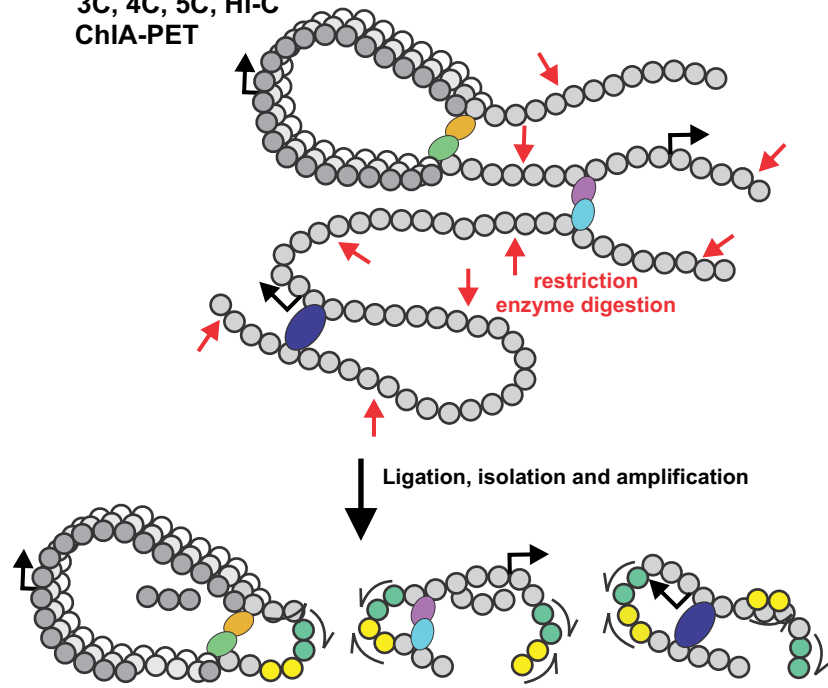

Figure 1

Illustration of current techniques utilized to study enhancer elements through population-based assays and single-molecule approaches. (A) Mapping of open chromatin accessibility via DNase-, ATAC- or FAIRE-seq. Nuclease such as DNase I or transposase such as Tn5 can target hypersensitive region (black arrows). The hypersensitive region is marked in red with the ability to detect the TF footprint at this region. The protection by the TF in the footprint is usually counted as number of cuts per bp (no. of cuts/bp). (B) Mapping of nucleosome positioning using MNase-seq. Micrococcal nuclease (MNase) preferentially cuts DNA strand between nucleosomes (black arrows) enabling chromatin structure mapping. (C) Mapping of the genomic location of TF (colored ovals) and chromatin modifications (small orange or green circles) by ChIP-seq and ChIP-exo. The TF or histone modification of interest is targeted by an antibody located at open or closed regions of chromatin. (D) The capture of chromatin interactions via 3C, 4C, 5C, Hi-C and ChIA-PET. Illustrations demonstrate the restriction enzyme digestion, ligation, isolation and amplification interaction events. Depending on the technique used, different degrees of interaction can be captured and measured. (E) Capture of single molecules bound to a fluorescent tag demonstrating TF (red oval) diffusing in the nucleus of the cell (orange arrow), scanning the genome (green square), and binding to a response element (blue square). (F) Live cell fluorescent imaging of a TF with post-translational labeling tag upon activation via a fluorescent ligand can be tracked in the nucleus and a residence time of the bound molecules can be determined. Orange represents a diffusing molecule, green a fast bound molecule and blue a TF binding at response elements termed slow bound. White scale bar $5 \mu \mathrm{m}$. ATAC, assay for transposase-accessible chromatin; ChIP, chromatin immunoprecipitation; FAIRE, formaldehyde-assisted isolation of regulatory element; TF, transcription factor. 


\section{Open chromatin mapping}

The most widely utilized assay for measuring the DNA accessibility is the DNase hypersensitivity assay followed by sequencing (DNase-seq) (Fig. 1A) (Boyle et al. 2008). This technique was based on the initial concept that nucleases can preferentially cut chromatin at regions with disrupted nucleosome structure (DNase I hypersensitive sites (DHSs)) (Keene et al. 1981, McGhee et al. 1981). Mapping DHSs in breast cancer can be used to identify chromatin sites that influence cancer development (D'Antonio et al. 2017). Formaldehyde-assisted isolation of regulatory elements (FAIRE)-seq is an alternative technique whereby chromatin is cross-linked using formaldehyde, sonicated and then phenol-chloroform extracted. The fragments in the aqueous phase are considered to derive from accessible regions and are sequenced (Gaulton et al. 2010). In general, FAIRE-seq and DNase-seq can identify the same open chromatin sites (Song et al. 2011); however, there are also unique regions identified by both techniques. More recently, an assay for transposase-accessible chromatin (ATAC)-seq has been developed. This alternative technique assays for accessible chromatin using the hyperactive Tn5 transposase (Buenrostro et al. 2013). Here, Tn5 will cut and insert sequencing adapters to open chromatin sites, which enables direct deep sequencing and mapping of genome-wide chromatin accessibility from the sample.

ATAC-seq is gaining favor over DNase- and FAIRE-seq, due to the small amount of starting material required and the much faster time to affect the assay. It can also be used for frozen as well as fresh tissue samples (Corces et al. 2017). The limits of DNase-seq and ATAC-seq have been extensively explored. Both these assays have been performed on single cells (Buenrostro et al. 2015, Cooper et al. 2017); in addition to measuring chromatin accessibility, DNase-seq and ATAC-seq data can be utilized to measure TF footprints (Buenrostro et al. 2013, Baek et al. 2017). The short region within an accessible enhancer sequence that is bound by a TF is sometimes protected from enzymatic attack. This level of protection provides a TF footprint (Galas \& Schmitz 1978, Neph et al. 2012, He et al. 2014, Sung et al. 2016). If the DNA cut fragments are sequenced with enough depth, the number of cuts per base pair (no. of cuts/bp) can be determined. The footprint can be quantified by an aggregation cut count plot across the motif and motif-flanking regions (Baek \& Sung 2016) (Fig. 1A (bottom)). These TF footprints have been described as a signature of TF binding to the protected site from a single experiment (Siersbaek et al.
2014, Stergachis et al. 2014). However, we and others have recently demonstrated that many TFs lack a detectable footprint (He et al. 2014, Sung et al. 2014, 2016, Baek et al. 2017). The 'absence' of these footprints is likely related to the rapid exchange observed for many TFs on chromatin in living cells (see the 'Live cell fluorescent imaging' section below).

\section{Nucleosome mapping}

Characterization of chromatin accessibility is valuable tool assessing the status of active chromatin landscape. However, the techniques mentioned earlier do not provide adequate information on the structure of chromatin, specifically, the positions of nucleosomes. This can be achieved with genome-wide nucleosome mapping by digestion of the chromatin with micrococcal nuclease (MNase) (Schones et al. 2008). This nuclease preferentially attacks linker regions between nucleosomes (Fig. 1B). Thus, sequencing the DNA fragments insensitive to MNase digestion produces a map of nucleosome positions, or the lack thereof. Traditional mapping of nucleosome positions around promoters has been used to determine gene activity, as active promoters tend to be nucleosome depleted. For TF-binding events, nucleosome content can be used to evaluate whether factors can bind to nucleosomal DNA (Ballare et al. 2012, Iwafuchi-Doi et al. 2016). This approach has been used as a rationale to determine whether TFs act as pioneer factors (further details below). Although MNase-seq is a powerful technique to map nucleosome positions, there are potential drawbacks. MNase digestion has a sequence preference, with digestion occurring at A/T-rich regions over G/C-rich regions. Furthermore, due to exonuclease activity of the MNase, nucleosome position can be altered due to concentration of MNase utilized in the experiments (Chereji et al. 2017, Lai \& Pugh 2017, Voong et al. 2017). To overcome this issue, MNase-seq experiments are often performed at differing concentrations of enzymes. This facilitates a more accurate evaluation of nucleosome positions (Iwafuchi-Doi et al. 2016). In addition to MNase-seq, several other techniques, such as ATAC-seq and RICC-seq (using ionizing radiation) have the capabilities to map nucleosome positions (Buenrostro et al. 2013, Risca et al. 2017). Furthermore, an increased resolution of nucleosome positions can be achieved using chemical cleavage mapping of nucleosome centers (Voong et al. 2016, Voong et al. 2017). 


\section{TF and modification mapping}

One of the most highly used techniques to study TF binding to chromatin to date is chromatin immunoprecipitation (ChIP) (Solomon et al. 1988, Orlando \& Paro 1993). This technique, (Fig. 1C) uses cross-linking (via formaldehyde), DNA fragmentation (sonication) and immunoprecipitation to capture all the occupying sites for a given protein, such as TF, cofactor or histone modification (Massie \& Mills 2008). Before the wide availability of deep sequencing, chromosome-wide mapping of TF action, such as ER, was mapped using the ChIP-on-chip (ChIP coupled with tiling array) technique (Carroll et al. 2005). Soon after the discovery of this technique, ChIP was coupled with deep sequencing (ChIP-seq) (Johnson et al. 2007, Robertson et al. 2007), allowing the genome-wide mapping of TFs, (including ER)-binding events (Welboren et al. 2009). Due to the ease of accessibility to deep sequencing platforms, ChIP-seq has become thestandard techniquetocharacterize the genome-wide occurrence of a given protein (Furey 2012). However, some of the binding events mapped by ChIP-seq can arise from non-specific enrichment, creating a phenomenon termed 'Phantom peaks' (Jain et al. 2015). Thus, several controls are needed to discriminate between a real binding and a false peak. As a result, a substantial number of modifications to the technique have been introduced, improving and expanding the output of the data. The usage of exonuclease digestion with bound protein of interest protecting the binding site (ChIP-exo) increases the resolution to a single-nucleotide level (Rhee \& Pugh 2011). Furthermore, ChIP-seq can be performed on single cells (Rotem et al. 2015), and coupling mass spectrometry to ChIP enables the detection of interactomes at the chromatin level (Mohammed et al. 2013, Rafiee et al. 2016). The ChIP-seq technique is by no means restricted to cell lines and fresh tissue samples, as ChIP-seq can also be performed from fixed clinical samples (Cejas et al. 2016) and core needle biopsy samples (Zwart et al. 2013). Thus, recent developments in sequencing techniques now enable researchers to perform both open chromatin techniques (Jin et al. 2015, Corces et al. 2017), as well as TF-binding mapping from clinical samples (Cejas et al. 2016), as well as older cataloged material.

\section{Chromatin conformation mapping}

After the realization that many TFs-binding events are located at far distances from promoters, several methods to characterize long-range chromosomal interactions were developed (Bernstein et al. 2012, Thurman et al.
2012, Davies et al. 2017). Most of these techniques are based on the digestion and ligation of interacting sites, termed chromosome conformation capture (3C) (Fig. 1D) (Dekker et al. 2002, Davies et al. 2017). However, newer techniques are emerging that allow the study of genomewide interaction of these sites (Beagrie et al. 2017) such as genome-wide 3C, called Hi-C, (Lieberman-Aiden et al. 2009) and chromatin interaction analysis by paired-end tag sequencing (ChIA-PET) (Fullwood et al. 2009). While these techniques are similar, Hi-C is used to map all DNADNA interactions while ChIA-PET uses ChIP to pre-select specific TF-interacting sites. Initially, Hi-C was capable of 1 megabase resolution (Lieberman-Aiden et al. 2009), while ChIA-PET could identify individual interactions on a kilobase resolution due to antibody selection (Li et al. 2010). However, improvements in Hi-C technique (in situ Hi-C) have enabled the detection of interactions in $1 \mathrm{~kb}$ resolution (Rao et al. 2014). This detailed resolution was achieved by performing the DNA-DNA proximity ligation in intact nucleic and deeply sequencing the data. Higher resolution in Hi-C can also be increased by focusing on certain interactions such as promoters via capture enriched Hi-C (Schoenfelder et al. 2015, Javierre et al. 2016). Both Hi-C and ChIA-PET techniques have been used to study chromatin architecture in breast cancer. Hi-C data clearly shows that interactions differ between mammary epithelial and breast cancer cells (Barutcu et al. 2015). Furthermore, ER (Fullwood et al. 2009) and RNA polymerase II (Li et al. 2012) ChIA-PET in breast cancer cells indicates that they are anchored to promoters through long-range interactions.

\section{Live cell fluorescence imaging}

All the above-mentioned assays are valuable tools to characterize the action of TFs. However, they suffer from two major drawbacks; the assays average signals across populations of heterogeneous cells and rely on dead cells. While biochemical and population-based assays suggest that TFs are assembled in a well-ordered manner to chromatin, live cell fluorescent imaging has indicated a more stochastic assembly (Stasevich \& McNally 2011, Coulon et al. 2013). This difference arises due to the temporal resolution of biochemical and populationbased assays, which cannot resolve the dynamic binding of TFs that occurs in live cells (Hager et al. 2009). In the past 15 years, several fluorescent microscopy techniques, such as fluorescent recovery after photobleaching (FRAP) and fluorescent correlation spectroscopy (FCS), have been used to resolve the dynamic action of TFs 
(Mueller et al. 2013). Many early FRAP experiments indicated that TF binding to chromatin occurs in the range of seconds (McNally et al. 2000, Stenoien et al. 2001). Furthermore, the rapid exchange of TFs with chromatin can influence the transcriptional output (Stavreva et al. 2004, Karpova et al. 2008). Although FRAP and FCS can be used to resolve milliseconds to minute range dynamic processes, both techniques are restricted to molecular populations in single cells. Hence, FRAP data will mostly represent diffusing TFs rather than bound ones. Recent advancements in imaging technologies (Tokunaga et al. 2008, Gebhardt et al. 2013, Chen et al. 2014), protein tags (Gautier et al. 2008, Los et al. 2008) and fluorescent dyes (Grimm et al. 2015) have enabled direct measurement of TF action at the single-molecule level (Mazza et al. 2012). This technique, known as single-molecule tracking (SMT) or single-particle tracking (SPT), utilizes bright and stable fluorophores, and electron multiplying charge coupled device (EMCCD) cameras to resolve fluorescent signals originating from single fluorophores (Presman et al. 2017). Several recent reviews have extensively covered the details and challenges of SMT (Liu et al. 2015, Manzo \& Garcia-Parajo 2015, Vera et al. 2016, Liu \& Tjian 2018, von Diezmann et al. 2017). Single molecules in general can be divided into two modes, bound and unbound states (Fig. 1E) (Paakinaho et al. 2017). It has been suggested that unbound molecules that can be captured on a singleframe but not tracked represent diffusing molecules (Fig. 1F). These diffusing molecules can be classified into several types of diffusion (Mazza et al. 2012, Izeddin et al. 2014)

Many investigators in the field have adopted an empirical method to describe the dynamics of bound molecules. This method involves fitting the dwell time data to alternate exponential distributions and choosing the model that provides the best fit (Chen et al. 2014, Morisaki et al. 2014, Kilic et al. 2015, Sugo et al. 2015, Ball et al. 2016, Schmidt et al. 2016, Zhen et al. 2016, Hansen et al. 2017, Kieffer-Kwon et al. 2017, Loffreda et al. 2017). The most frequent models currently invoked argue for two or three component distributions for the bound fraction. In a two component version, fast bound molecules are proposed to represent non-specific binding. The TF scans the genome attempting to find its specific binding sites remaining bound only for short period of time (Fig. 1E and F) (Elf et al. 2007, Chen et al. 2014, Paakinaho et al. 2017). In contrast, slow bound molecules remain bound for longer periods (5-15s) and are proposed to represent TF binding to specific response element (Fig. 1E and F). In support of this interpretation, mutating the DNA-binding domain of a TF drastically reduces or abolishes the slow bound population of single molecules (Chen et al. 2014, Morisaki et al. 2014, Sugo et al. 2015, Paakinaho et al. 2017). Work in breast cancer cell lines has indicated that chromatin binding of SRs is a very dynamic process (Swinstead et al. 2016a). Interestingly, the pioneer factor FoxA1 (to be described below) also displays rapid dynamics in breast cancer cells. Essentially, all TFs studied so far show dynamic action at the singlemolecule level in live cells (Mazza et al. 2012, Chen et al. 2014, Morisaki et al. 2014 Sugo et al. 2015, Teves et al. 2016, Zhen et al. 2016,, Paakinaho et al. 2017, Goldstein et al. 2017a), while structural proteins such as CTCF show much slower binding dynamics (Hansen et al. 2017). It should be emphasized that current interpretations for SMT are not based on rigorous thermodynamic models. It is likely that more accurate descriptions of real-time $\mathrm{TF} /$ chromatin interactions will emerge. However, current results clearly demonstrate that $\mathrm{TF}$ action in general is a very rapid and dynamic process. Eventually populationbased and live cell fluorescent microscopy perspectives should be resolved within a single comprehensive model (Paakinaho et al. 2017). We are already beginning to see this combination with the development of synthetic techniques such as ATAC-see (Chen et al. 2016).

\section{Enhancer reprogramming modes of TFs}

Enhancers are short stretches of regulatory elements generally located distal to promoters. During transcriptional regulation, TFs reprogram enhancers by altering chromatin accessibility thereby influencing the recruitment of other factors including RNA polymerases. Thus, the initial enhancer reprogramming determines the transcriptional outcomes (Smith \& Shilatifard 2014, Schaffner 2015). To reprogram enhancers and regulate transcription, TFs must be able to access enhancer regions on chromatin. Current models envisage TFs binding and enhancer reprogramming through five major modes (Fig. 2) (Spitz \& Furlong 2012, Voss \& Hager 2014, Long et al. 2016).

\section{Cooperative TF binding}

It has been generally proposed that TFs require cooperative action of two of more factors to gain access to binding sites in closed chromatin regions (Fig. 2A), through direct or indirect interactions (Spitz \& Furlong 2012, Long et al. 2016). These events are thought to be ATP dependent, requiring the recruitment of chromatin 
A

\section{Cooperative TF binding}

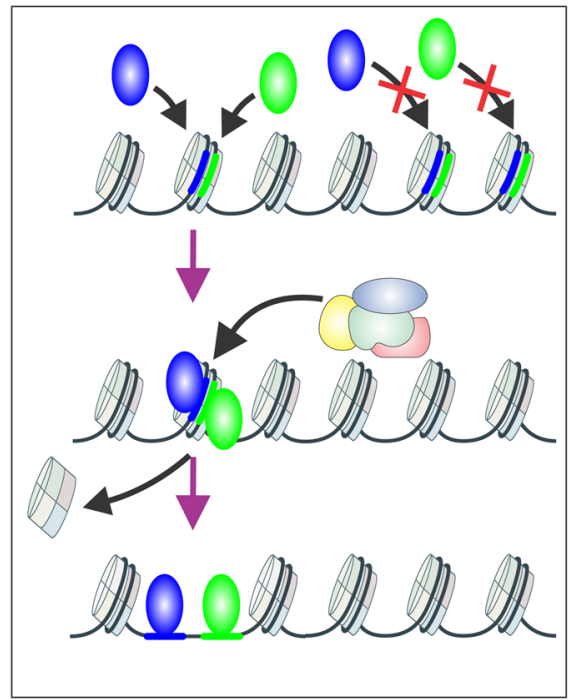

B

Pioneer factor binding

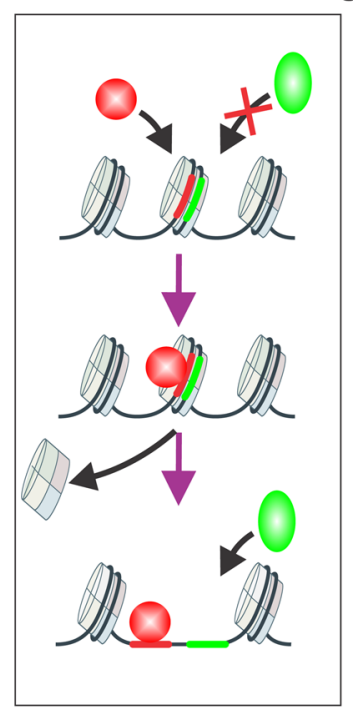

C

Dynamic assisted loading

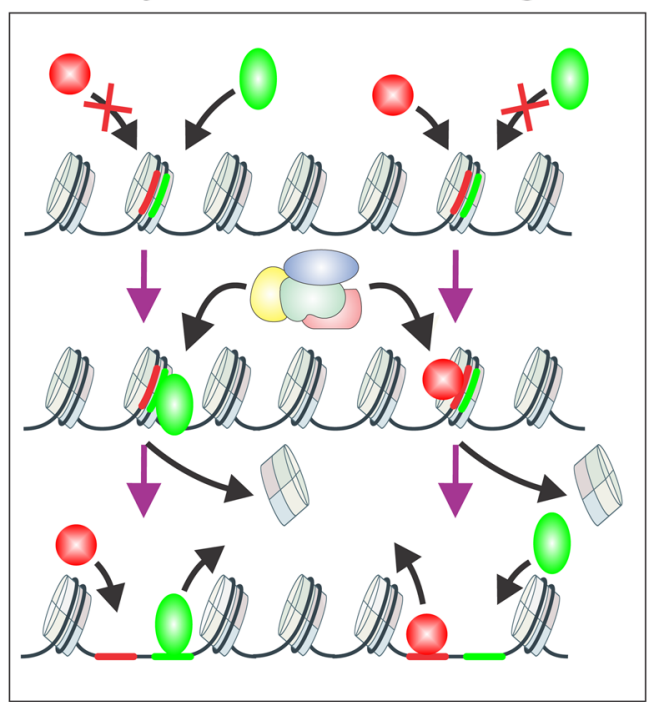

D

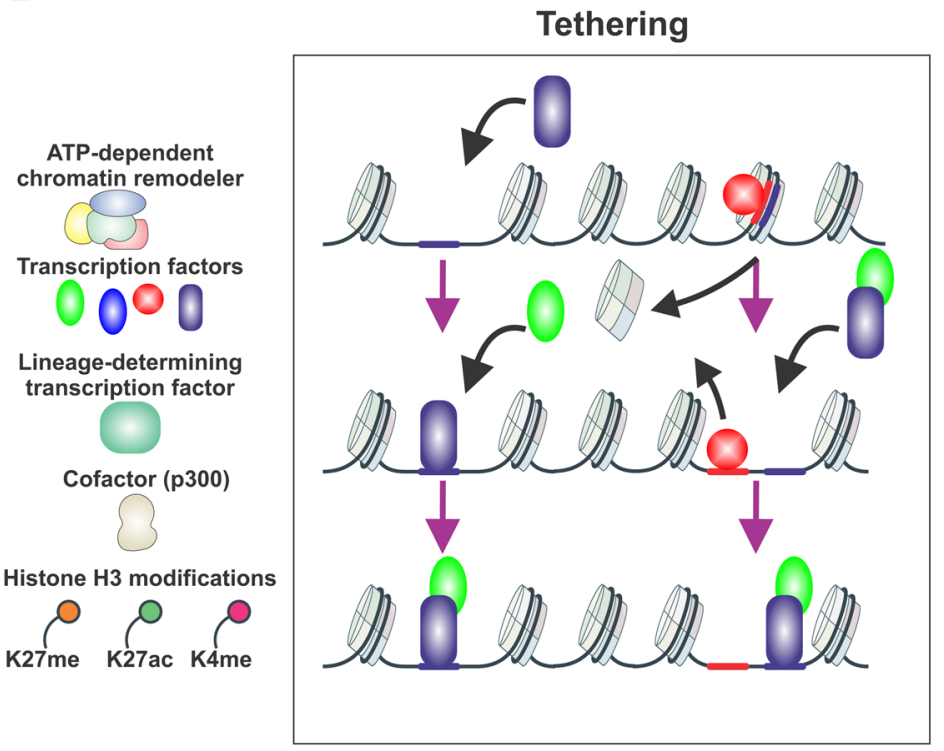

E

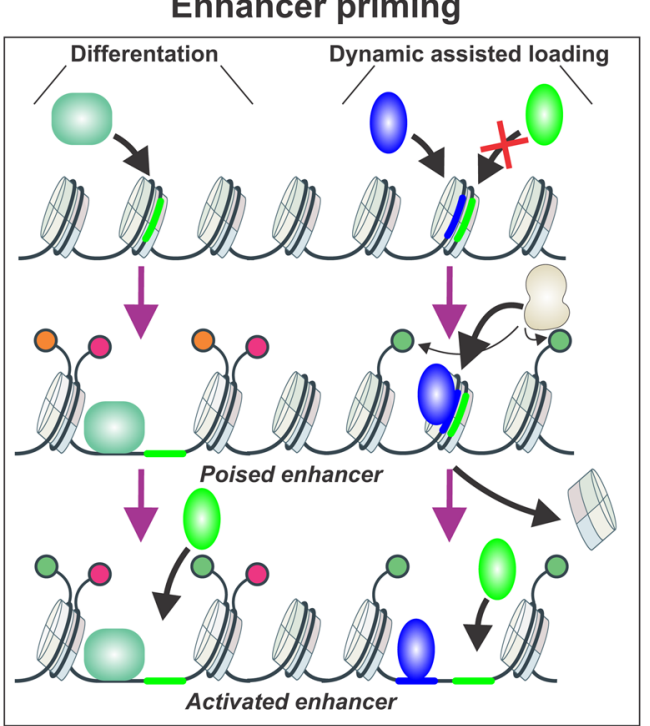

Figure 2

Illustration of enhancer reprogramming models. (A) Cooperative TF-binding model. The binding region of interest is inaccessible until two TF concomitantly binding, recruit chromatin remodeling factors resulting in an accessible region. (B) Pioneer factor binding. Pioneer factors such as FoxA1 bind to closed regions of chromatin, expel the nucleosomes, allowing binding of a secondary factor in the absence of ATP-dependent processes. (C) Dynamic-assisted loading. The initiating factor binds to a closed chromatin region, upon recruitment of chromatin remodeling factors the secondary factor can binding to a region previously deemed inaccessible. This is usually a bimodal switch between two TF depending on the chromatin landscape and the enhancer region. (D) The tethering model. One TF binds to a chromatin region with the secondary TF recruited upon binding or initially tether to the first TF. (E) Enhancer priming. This mechanism is functional in differentiation or dynamic assisted loading. The bound lineage-determining TF can alter the chromatin landscape by changing enhancer accessibility and histone modifications. Conversely, in assisted loading, the initiating factor binding activates enhancer region by increasing active histone modifications inducing the recruitment of the secondary factor to these sites. In both cases, poised enhancer state exists between the inactive and active enhancer states. TF, transcription factor. 
remodeling complexes enabling an alteration to chromatin accessibility. The direct interaction model relies on a physical contact or simultaneous binding between the cooperative TFs. Furthermore, TF pairs can have closely proximal recognition motifs on DNA influencing TF concomitant binding (Jolma et al. 2015, Morgunova \& Taipale 2017). In the case of indirect interaction, cooperativity occurs without apparent physical contact but with TFs binding in close proximity to each other. For some TFs, the indirect interaction mode can be classified as pioneer action (to be described). It is likely that both direct and indirect cooperative action can occur simultaneously. For example, it was recently described that during reprogramming of somatic cells to pluripotency (Takahashi \& Yamanaka 2006), Oct4, Sox2 and Klf4 interact cooperatively to reprogram enhancers for pluripotency (Chronis et al. 2017). However, this cooperative action can function in the pioneer factor mode to induce the binding of somatic TFs. Further, during $\mathrm{T}$ cell activation, two pairs of TFs can cooperatively act to reprogram a different set of enhancers (Bevington et al. 2016). In this case, enhancer priming (to be described) is regulated by the cooperative action of ETS-1 and RUNX1, while activation of inducible enhancer is regulated by AP-1 and NFAT. Interestingly, integration of several genomic and interactome datasets can identify several layers of cooperative TF action in liver (Dubois-Chevalier et al. 2017) and during adipogenesis (Siersbaek et al. 2014). Finally, cooperative TF binding most likely influences enhancer activity since it is seemingly dependent on the other TFs in the immediate vicinity rather than an actual TF-binding event (Grossman et al. 2017).

\section{Pioneer factor binding}

It has been postulated that most TFs act in a cooperative manner. However, pioneer factors have been described as a small class of unique TFs that can penetrate chromatin on their own and assist the binding of non-pioneer proteins to the chromatin (Fig. 2B) (Zaret \& Carroll 2011, Drouin 2014). This group includes Oct4, Sox2, Klf4 (Soufi et al. 2015), factors that reprogram somatic cells to pluripotency, and GATA and FoxA family members (Cirillo et al. 2002). In addition, Pax7 can act as pioneer factor in pituitary melanotrope cells (Mayran et al. 2018). Their capability to bind and remodel nucleosomes is the major characteristic of a pioneer factor (Zaret \& Mango 2016). In the case of Oct 4 , Sox 2 and Klf4, these factors can recognize their motifs on the surface of nucleosomes (Soufi et al. 2015), and increase the binding of other non-pioneer factors. In comparison, FoxA also has capability to bind to core histones (Cirillo et al. 2002); however, the structure of FoxA's DNA-binding domain resembles that of linker histone H1 (Zaret \& Carroll 2011). This suggests that FoxA can efficiently displace $\mathrm{H} 1$ from the chromatin thus maintaining accessible chromatin (Iwafuchi-Doi et al. 2016). Pax7 can bind to heterochromatin regions and slowly promote chromatin opening providing epigenetic memory (Mayran et al. 2018). Most interesting is the proposal that the action of pioneer factors occurs in an ATP-independent fashion (Cirillo et al. 2002). However, recent discoveries suggest, at least for Oct4 and GATA pioneer factors, that ATP-dependent chromatin remodeling complexes are required for efficient pioneer factor function during enhancer reprograming (Swinstead et al. 2016b, Takaku et al. 2016, King \& Klose 2017). Interestingly, the pioneer activity of FoxA2, Oct 4 and GATA4 is not increased by ectopic expression of the factor (Donaghey et al. 2018). However, the activity of FoxA2 is increased when coexpressed together with GATA4, suggesting that pioneer factors might operate in cooperative manner.

Pioneer factors, particularly FoxA1, have been shown to be exceptionally important for SR recruitment (Lupien \& Brown 2009, Zaret \& Carroll 2011). A major fraction of chromatin binding for both ER and AR depends on the pioneer activity of FoxA1 (Lupien et al. 2008, Hurtado et al. 2010, Robinson et al. 2011), with GATA3 also playing a pioneer role for ER in breast cancer (Theodorou et al. 2012). In the case of GR, AP-1 functions as a pioneer factor for a significant fraction of the receptor binding events (Biddie et al. 2011, John et al. 2011). While it has been suggested that SRs themselves can function as pioneer factors, the mechanism behind the SR 'pioneer activity' appears to be more complex than the classically described process (Sahu et al. 2011, Swinstead et al. 2016a).

\section{Dynamic-assisted loading}

Based on in vitro experiments, it is expected that TFs that bind to the same DNA sites would in fact compete for binding. However, it was shown in vivo that two SRs failed to compete for the same binding site; rather one receptor assisted the binding of the secondary receptor (Voss et al. 2011). These findings led to the proposal of a new model, termed 'dynamic-assisted loading'. In this model, one TF binds to a closed chromatin site, induces chromatin remodeling though ATP-dependent processes, and thereby assists the binding of the second TF to the site (Fig. 2C). It is further suggested that competition does not 
occur at the assisted loading sites in vivo due to the rapid interaction of TFs with chromatin in live cells (Swinstead et al. 2016a, Paakinaho et al. 2017). Furthermore, some TFs have been shown to be mobile during chromatin remodeling reactions (Nagaich et al. 2004, Li et al. 2015). In this scenario, the initiating $\mathrm{TF}$ inducing chromatin remodeling is actively displaced by the remodeler before the binding of the assisted factor. The assisted loading model differs from the cooperative and pioneer model in several distinct ways (Swinstead et al. 2016b). In comparison to the cooperative model, the two factors do not physically interact. In addition, assisted loading can be a symmetric event, with one factor acting as an initiator at some sites, while the other acts as initiator at different sites. This bimodal symmetry highlights the difference of assisted loading from the pioneer model. Furthermore, ATP-dependent chromatin remodeling factors are crucial for assisted loading, while the classically described pioneer model suggests ATP-independent action.

Although assisted loading occurs in a symmetric manner, it also occurs in an enhancer-specific manner. This is a major mechanism of enhancer reprograming for SRs (Grontved et al. 2013, Swinstead et al. 2016a, Goldstein et al. 2017a) and other nuclear receptors (Madsen et al. 2014, Soccio et al. 2015) in various cellular contexts. For example, GR will assist the binding of ER at a subset of enhancers while ER will assist the binding of GR at another subset of enhancers (Miranda et al. 2013). In addition to nuclear receptors, other TFs have been described to also operate through the assisted loading mechanism ( $\mathrm{Zhu}$ et al. 2015, Goldstein et al. 2017b).

\section{Tethering}

An alternative model for TF function at enhancers involves a tethering event, whereby one TF can access an assessable site by physically tethering to another TF (Fig. 2D). Genome-wide ChIP-seq studies alone are insufficient to determine if a binding event is a classical direct binding event or a tethering paradigm. Consequently, the DNA that is immunoprecipitated by the antibody of interest will represent sites of direct binding events, as well as sites of protein-protein interaction. DNA-binding motif identification is frequently used to distinguish between these modes of action.

Classically, the anti-inflammatory action of GR is thought to be the consequence of GR tethering to proinflammatory factors thereby inhibiting their action (Petta et al. 2016, Cain \& Cidlowski 2017). However, recent results suggest that tethering might not be as prominent a mode of action as was previously believed (Uhlenhaut et al. 2012, Oh et al. 2017). Furthermore, GR can tether to other TFs without inflammatory stimuli to influence their action (Langlais et al. 2012). In the case of classical ER-binding events, the receptor binds to an estrogen response element (ERE); however, there are a number of identified sites missing the canonical ERE, suggesting a tethering phenomenon. Specifically, in MBA-MD-231 cells, breast cancer cells transfected with WT ER- or DBDmutant ER incapable of binding to EREs; there is a clear difference between the transcription profiles of the two receptors (Stender et al. 2010). This segregation was used to identify direct ER binding or tethering events. As tethered sites were enriched for the RUNX motif in the absence of an ERE, it was concluded that ER tethers RUNX to mediate DNA-independent gene regulation (Stender et al. 2010). It is important to note that the tethering event is largely different from the dynamic-assisted loading model. Specifically, during dynamic-assisted loading, there is a presence of binding response elements of both TFs (initiating and secondary) (Swinstead et al. 2016a). However, there can be collaboration between the tethering and the dynamic-assisted loading model. At a population of ER sites that are assisted by GR, AP-1 is tethered to ER facilitating the binding of ER at a number of assisted loading sites (Miranda et al. 2013). However, because formaldehyde crosslinks both DNA-protein and protein-protein interactions, the tethering mode can only be proposed but not confirmed by ChIP assays. Alternative techniques should be used, such as expression of DBD-mutant TFs (Stender et al. 2010, Langlais et al. 2012). In addition, the improved resolution obtained by ChIP-exo can be used to distinguish direct DNA-binding and tethering events (Starick et al. 2015). More sophisticated techniques are being harnessed to address these issues. Previously, UV-laser cross-linking has been used in vitro (Nagaich et al. 2004), to study direct DNA binding of TFs. Interestingly, very recently it has been shown that UV-laser cross-linking can be coupled to ChIP (Steube et al. 2017) to resolve tethering events from direct DNA binding. Future development of this technique will further help to distinguish protein-protein from protein-DNA interactions.

\section{Enhancer priming}

The selection and function of TF-binding events can prime the enhancer for a resultant transcriptional response (Fig. 2E). Enhancer priming is prevalent in differentiation. Specifically, a TF can bind, altering a poised enhancer to 
an activated enhancer through histone $\mathrm{H} 3$ modifications. This results in a recruitment of a secondary factor (Heinz et al. 2015). This has been most clearly shown in the differentiation of hematopoietic cells, where lineagedetermining factors, such as PU.1, prime enhancers for macrophage or B cell differentiation (Heinz et al. 2010). Eventually, these primed enhancers will serve as a platform for signal-dependent TF binding driving differentiation to a specific direction. Furthermore, H3K4 methylation and enhancer transcription seem especially important for enhancer priming (Heinz et al. 2010, Kaikkonen et al. 2013). Another example of enhancer priming is illustrated in the phenomenon of $\mathrm{T}$ cell memory acquisition. Here, activation of T cells induces NCAT and AP-1 binding, resulting in a number of new DHS site and subsequent recruitment of ETS-1 and RUNX1. Interestingly, the DHSs remained stable long after $\mathrm{T}$ cell activation, maintaining open chromatin regions at active enhancer regions (Bevington et al. 2016). The dynamic-assisted loading model can be extended further with evidence for enhancer priming. The dynamic crosstalk between two factors through this interaction results in alteration of H3K27ac and an associated recruitment of P300 (Goldstein et al. 2017b).

\section{Enhancer reprogramming by SRs in breast cancer}

Specifically relevant to breast cancer, a number of investigators are beginning to examine the mechanistic processes of SR recruitment to enhancer elements. Many of the enhancer reprogramming modes are utilized by SRs in breast cancer. These studies have explored the different modes of action a SR can have on the chromatin landscape and the consequential output for gene regulation and transcription profiles. Cooperative action among SRs is beginning to appear as a major mode of enhancer reprogramming in breast cancer cells (see next section for details). However, other pathways can cooperatively reprogram enhancers with SRs. Growth factors, independently or in cooperation with ER, can reprogram the enhancer landscape influencing the ER cistrome in breast cancer cells (Lupien et al. 2010). Interestingly, in non-tumorigenic mammary cells, growth factors and GR can act in a cooperative and antagonistic manners to reprogram enhancers and gene regulation (Enuka et al. 2017). In addition to growth factors, inflammatory pathways can reprogram the ER enhancer landscape potentially influencing clinical outcome of breast cancer (Franco et al. 2015), or endocrine resistance
(Stender et al. 2017). Thus, it is expected that other signaling pathways will cooperatively influence SR enhancer reprogramming. In addition, mutations in ER (ESR1) arising from endocrine resistance, can reprogram ER binding (Martin et al. 2017, Toy et al. 2017, Jeselsohn et al. 2018), influencing receptor action on chromatin. In the case of tethering, Carroll and colleagues reported that activated PR could reprogram the ER enhancer landscape, contributing to an inhibition of breast cancer tumor growth under the dual treatment conditions. These newly acquired ER sites under the dual activation of both receptors was proposed to be through a tethering event, whereby PR and ER physically interact with cofactors and FoxA1 at binding sites. It was proposed that there is a lack of a classical ERE at these unique sites (Mohammed et al. 2015). Myers and colleagues have also suggested that celltype-specific ER and GR binding events that lack a strong canonical response element represent tethering events (Gertz et al. 2013). Interestingly, this model also suggests that these SR tethered enhancers are primed by other TFs. These results imply that in some cases SRs can have only a minor effect on enhancer reprogramming as they bind to already accessible chromatin. This is in line with the pioneer factor model, where SRs binding is dictated by other TFs (Hurtado et al. 2010, Biddie et al. 2011, John et al. 2011, Theodorou et al. 2012). As indicated above, the main property of a pioneer factor is the capability to bind histones at closed chromatin sites (Zaret \& Carroll 2011, Drouin 2014).

In this vein, SRs can target nucleosomes in breast cancer cells transforming them to bona fide pioneer factors. It has been suggested that the vast majority of ER and $\mathrm{PR}$ binding regions are largely nucleosome rich (Ballare et al. 2012, He et al. 2012) (Fig. 3A and B). ER binding in breast cancer cells is largely marked by H3K4me2 implying nucleosome rich binding regions (He et al. 2012) (Fig. 3A). However, whether ER binds to nucleosomes without an H3K4me2 mark or how chromatin remodelers influence these processes is unknown. In the case for PR, Beato et al. described PR-binding events at PRE-enhancer regions rich with nucleosomes. The majority of sites are DNase I hypersensitive, and hormone activation results in displacement of $\mathrm{H} 1$ and $\mathrm{H} 2 \mathrm{~A} / \mathrm{H} 2 \mathrm{~B}$ dimers (Ballare et al. 2012) (Fig. 3B). Further, it has been described that Brg1 is largely involved in the resultant gene transcriptional response at enhancer regions (Ceballos-Chavez et al. 2015). Thus, two important factors for breast cancer development, ER and PR, can both act as pioneer factors, and at least ER can regulate the binding of other factors by this pioneer activity (Swinstead et al. 2016a). For GR, initial 
A

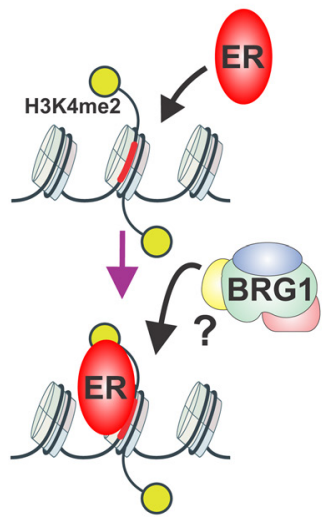

B

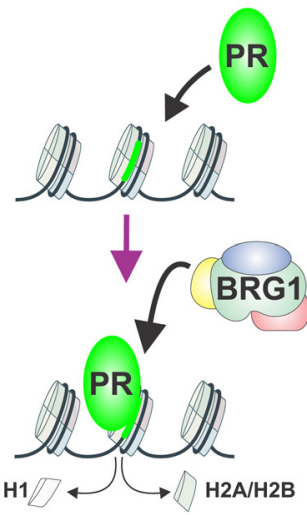

C

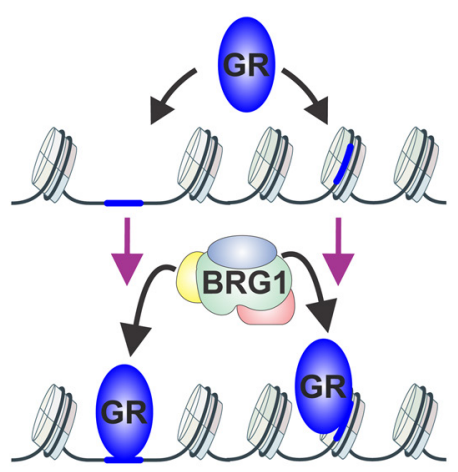

Figure 3

Nucleosomal enhancer reprogramming by steroid receptors in breast cancer. (A) ER is bound to regions largely marked by $\mathrm{H} 3 \mathrm{~K} 4 \mathrm{me} 2$ and rich in nucleosomes. ER potentially recruits chromatin remodelers to increase chromatin accessibility. (B) PR binds to nucleosome rich regions, recruits the Brg1 chromatin remodeler, resulting in a hypersensitive site and displacement of $\mathrm{H} 1$ and H2A/H2B dimers. (C) GR can bind to nucleosomedepleted sites or sites enriched with a nucleosome. The nucleosomal-depleted GR enhancers are marked with Brg1. GR sites that are rich with nucleosomes are suggestive of dynamic-assisted loading or the pioneer model. $E R$, estrogen receptor; GR, glucocorticoid receptor; $\mathrm{PR}$, progesterone receptor. genome-wide studies indicated frequent binding at sites with pre-existing DNase hypersensitivity. This accessibility is often interpreted as areas lacking nucleosomes (John et al. 2011) (Fig. 3C). However, we have recently completed high-resolution nucleosome positioning studies and discovered that many DHS elements retain modified nucleosomes. This has led to a refined view of the chromatin structures present at responsive GR enhancers (Johnson et al. 2018). In this view, they can be located either in pre-existing nucleosome-depleted regions or within a nucleosome (Fig. 3C). The nucleosomal-depleted GR enhancers are already marked with Brg1, a chromatin remodeling factor, and flanked by H2A.Z. However, GR sites that are rich with nucleosomes can be segregated further into i) DHSs associated with Brg1 or ii) sites insensitive to DNase I and lacking Brg1, suggestive of a true GR pioneer function by dynamic-assisted loading (Johnson et al. 2018) (Fig. 3C). Thus, although GR action differs from that of ER and PR, it can also act as a pioneer factor targeting nucleosomal chromatin sites. The association of Brg1 and SR transcriptional responses has been well characterized (Swinstead et al. 2016b). However, an in-depth understanding of how these different enhancer region states relate specifically to SR binding and transcriptional response in breast cancer remains incomplete.

\section{Collaborative crosstalk of SR-binding events}

Classically ER- and PR-binding events in breast cancer have been studied as single receptor-binding events. It is becoming apparent that i) SRs collaborate with each other by the various mechanisms described earlier and ii) there is an increasing appreciation for the importance of AR and GR signaling in breast cancer. The role of activated PR and the collaboration with ER signaling, and consequences for breast cancer growth is becoming well documented (Daniel et al. 2015, Mohammed et al. 2015, Hegde et al. 2016, Singhal et al. 2016, Finlay-Schultz et al. 2017). PR influences ER genomic recruitment (Mohammed et al. 2015, Singhal et al. 2016) potentially influencing decisions on breast cancer therapies. Interestingly, ER/PR crosstalk can be defined by PR isoforms, wherein PR-A inhibits while PR-B redistributes chromatin binding of ER (Singhal et al. 2018). In addition, recently, it was shown that PR can decrease the expression of proteins needed for translation, such as tRNAs in breast cancer (FinlaySchultz et al. 2017). This decrease of tRNAs will restrict the translation of ER-regulated genes related for breast cancer growth. This highlights the importance of looking at these factors in a common setting. In addition, AR has been described to facilitate ER binding at a number of loci with enzalutamide, an AR antagonist, attenuating the response (D'Amato et al. 2016). Furthermore, AR can collaborate with ER enhancing its transcriptional activity in aromatase-inhibited breast cancer cells (Rechoum et al. 2014). Lastly, the role of GR and ER crosstalk is emerging in the field, with several studies suggesting GR can induce or repress a number of ER-binding events (Miranda et al. 2013, Yang et al. 2017). Post-translational modifications of GR, such as those mediated by small ubiquitin-related modifier (SUMO; SUMOylation), are seemingly important in the repression of ER (Yang et al. 2017). However, this repression was only shown for a few SR-regulated loci. On a genome-wide level, GR SUMOylation finetunes GR chromatin occupancy (Paakinaho et al. 2014), suggesting that SUMOylation can have an even wider effect on SR crosstalk. Conversely, activated ER can result in enrichment of GR at proximal promoter regions, with increased GR chromatin association at ER-, FOX- and 
AP-1-binding response regions (West et al. 2016). The profiling of the SR landscape in human male breast cancer tumors indicates extensive overlap between ER, PR, AR and GR binding (Severson et al. 2018). This suggests that the interplay of SRs is also important in primary patient samples. Finally, analysis of nuclear receptor networks in breast cancer cells has revealed not only SRs interactions, but also complex interactions among nuclear receptors and other TFs related to breast cancer growth (Kittler et al. 2013).

While many studies have started to uncover the concomitant crosstalk of SRs in breast cancer biology, what is still unclear are the mechanisms associated with the collaboration. Whether these events occur through the pioneer factor model, dynamic-assisted loading, tethering or direct-binding events associated with other cofactors is still poorly understood at the level of molecular mechanism.

\section{Conclusion}

To date, the clear majority of studies investigating TF signaling in breast cancer have focused on individual SR-binding events. This is not a representative capture of the biologically important functions in the human body. Above we have provided an in-depth description of the dual collaboration of TFs on enhancer regulation. Lacking in the field of SR biology is a comprehensive understanding of the collaborative crosstalk of multiple SRs and other TFs at any given time, and the underlying mechanisms associated with these events. In addition, as many SRs in breast cancer cells can act as pioneer factors, existing models should be refined. It is becoming more apparent that there is no certain set of pioneer factors, but rather multiple TFs that in certain settings possess pioneering activities.

As we more fully understand the different types of SR-binding events in breast cancer and underlying chromatin landscape, we can assess the direct effects on gene transcriptional profiles. These events are critical to driving breast cancer progression and proliferation. This information will assist in the understanding of the complex and in-depth systems associated with TF biology in breast cancer and the effects that the chromatin landscape has on these events.

\section{Declaration of interest}

The authors declare that there is no conflict of interest that could be perceived as prejudicing the impartiality of this review.

\section{Funding}

This work was supported by the Intramural Research Program of the National Institutes of Health $(\mathrm{NIH})$, the National Cancer Institute $(\mathrm{NCl})$, the Center for Cancer Research (CCR). E E S was supported by the Office of the Assistant Secretary of Defense for Health Affairs, through the Breast Cancer Research Program under Award No. W81XWH-17-1-0067. Opinions, interpretations, conclusions and recommendations are those of the author and are not necessarily endorsed by the Department of Defense. V P was supported by the University of Eastern Finland strategic funding and the Sigrid Jusélius Foundation.

\section{References}

Arpino G, De Angelis C, Giuliano M, Giordano A, Falato C, De Laurentiis M \& De Placido S 2009 Molecular mechanism and clinical implications of endocrine therapy resistance in breast cancer. Oncology 77 (Supplement 1) 23-37. (https://doi. org/10.1159/000258493)

Baek S \& Sung MH 2016 Genome-scale analysis of cell-specific regulatory codes using nuclear enzymes. Methods in Molecular Biology 1418 225-240. (https://doi.org/10.1007/978-1-4939-3578-9_12)

Baek S, Goldstein I \& Hager GL 2017 Bivariate genomic footprinting detects changes in transcription factor activity. Cell Reports 19 1710-1722. (https://doi.org/10.1016/j.celrep.2017.05.003)

Ball DA, Mehta GD, Salomon-Kent R, Mazza D, Morisaki T, Mueller F, McNally JG \& Karpova TS 2016 Single molecule tracking of Ace1p in Saccharomyces cerevisiae defines a characteristic residence time for non-specific interactions of transcription factors with chromatin. Nucleic Acids Research 44 e160. (https://doi.org/10.1093/nar/gkw257)

Ballare C, Castellano G, Gaveglia L, Althammer S, Gonzalez-Vallinas J, Eyras E, Le DF, Zaurin R, Soronellas D, Vicent GP, et al. 2012 Nucleosome-driven transcription factor binding and gene regulation. Molecular Cell 49 67-79. (https://doi.org/10.1016/j. molcel.2012.10.019)

Barutcu AR, Lajoie BR, McCord RP, Tye CE, Hong D, Messier TL, Browne G, van Wijnen AJ, Lian JB, Stein JL, et al. 2015 Chromatin interaction analysis reveals changes in small chromosome and telomere clustering between epithelial and breast cancer cells. Genome Biology 16 214. (https://doi.org/10.1186/s13059-015-0768-0)

Beagrie RA, Scialdone A, Schueler M, Kraemer DC, Chotalia M, Xie SQ Barbieri M, de Santiago I, Lavitas LM, Branco MR, et al. 2017 Complex multi-enhancer contacts captured by genome architecture mapping. Nature 543 519-524. (https://doi.org/10.1038/ nature21411)

Beatson GT 1896 On the treatment of inoperable cases of carcinoma of the mamma: suggestions for a new method of treatment, with illustrative cases. Lancet 148 162-165. (https://doi.org/10.1016/ S0140-6736(01)72384-7)

Bennett RL \& Licht JD 2017 Targeting epigenetics in cancer. Annual Review of Pharmacology and Toxicology 58 187-207. (https://doi. org/10.1146/annurev-pharmtox-010716-105106)

Beral V 2003 Breast cancer and hormone-replacement therapy in the Million Women Study. Lancet 362 419-427. (https://doi.org/10.1016/ S0140-6736(03)14065-2)

Bernstein BE, Birney E, Dunham I, Green ED, Gunter C \& Snyder M 2012 An integrated encyclopedia of DNA elements in the human genome. Nature 489 57-74. (https://doi.org/10.1038/nature11247)

Beroukhim R, Mermel CH, Porter D, Wei G, Raychaudhuri S, Donovan J, Barretina J, Boehm JS, Dobson J, Urashima M, et al. 2010 The landscape of somatic copy-number alteration across human cancers. Nature 463 899-905. (https://doi.org/10.1038/nature08822)

Bevington SL, Cauchy P, Piper J, Bertrand E, Lalli N, Jarvis RC, Gilding LN, Ott S, Bonifer C \& Cockerill PN 2016 Inducible chromatin priming is associated with the establishment of
(C) 2018 Society for Endocrinology Published by Bioscientifica Ltd. Printed in Great Britain 
immunological memory in T cells. EMBO Journal 35 515-535. (https://doi.org/10.15252/embj.201592534)

Biddie SC, John S, Sabo PJ, Thurman RE, Johnson TA, Schiltz RL, Miranda TB, Sung MH, Trump S, Lightman SL, et al. 2011 Transcription factor AP1 potentiates chromatin accessibility and glucocorticoid receptor binding. Molecular Cell 43 145-155. (https:// doi.org/10.1016/j.molcel.2011.06.016)

Bignell GR, Greenman CD, Davies H, Butler AP, Edkins S, Andrews JM, Buck G, Chen L, Beare D, Latimer C, et al. 2010 Signatures of mutation and selection in the cancer genome. Nature 463 893-898. (https://doi.org/10.1038/nature08768)

Boulay G, Sandoval GJ, Riggi N, Iyer S, Buisson R, Naigles B, Awad ME, Rengarajan S, Volorio A, McBride MJ, et al. 2017 Cancer-specific retargeting of BAF complexes by a prion-like domain. Cell $\mathbf{1 7 1} 163$. e119-178.e119. (https://doi.org/10.1016/j.cell.2017.07.036)

Boyle AP, Davis S, Shulha HP, Meltzer P, Margulies EH, Weng Z, Furey TS \& Crawford GE 2008 High-resolution mapping and characterization of open chromatin across the genome. Cell 132 311-322. (https:// doi.org/10.1016/j.cell.2007.12.014)

Buenrostro JD, Giresi PG, Zaba LC, Chang HY \& Greenleaf WJ 2013 Transposition of native chromatin for fast and sensitive epigenomic profiling of open chromatin, DNA-binding proteins and nucleosome position. Nature Methods 10 1213-1218. (https://doi.org/10.1038/ nmeth.2688)

Buenrostro JD, Wu B, Litzenburger UM, Ruff D, Gonzales ML, Snyder MP, Chang HY \& Greenleaf WJ 2015 Single-cell chromatin accessibility reveals principles of regulatory variation. Nature $\mathbf{5 2 3}$ 486-490. (https://doi.org/10.1038/nature14590)

Cain DW \& Cidlowski JA 2017 Immune regulation by glucocorticoids. Nature Reviews Immunology 17 233-247. (https://doi.org/10.1038/ nri.2017.1)

Carroll JS, Liu XS, Brodsky AS, Li W, Meyer CA, Szary AJ, Eeckhoute J, Shao W, Hestermann EV, Geistlinger TR, et al. 2005 Chromosomewide mapping of estrogen receptor binding reveals long-range regulation requiring the forkhead protein FoxA1. Cell 122 33-43. (https://doi.org/10.1016/j.cell.2005.05.008)

Ceballos-Chavez M, Subtil-Rodriguez A, Giannopoulou EG, Soronellas D, Vazquez-Chavez E, Vicent GP, Elemento O, Beato M \& Reyes JC 2015 The chromatin remodeler CHD8 is required for activation of progesterone receptor-dependent enhancers. PLoS Genetics 11 e1005174. (https://doi.org/10.1371/journal.pgen.1005174)

Cejas P, Li L, O'Neill NK, Duarte M, Rao P, Bowden M, Zhou CW, Mendiola M, Burgos E, Feliu J, et al. 2016 Chromatin immunoprecipitation from fixed clinical tissues reveals tumorspecific enhancer profiles. Nature Medicine 22 685-691. (https://doi. org/10.1038/nm.4085)

Chawla A, Repa JJ, Evans RM \& Mangelsdorf DJ 2001 Nuclear receptors and lipid physiology: opening the X-files. Science 294 1866-1870. (https://doi.org/10.1126/science.294.5548.1866)

Chen J, Zhang Z, Li L, Chen BC, Revyakin A, Hajj B, Legant W, Dahan M, Lionnet T, Betzig E, et al. 2014 Single-molecule dynamics of enhanceosome assembly in embryonic stem cells. Cell $\mathbf{1 5 6}$ 1274-1285. (https://doi.org/10.1016/j.cell.2014.01.062)

Chen X, Shen Y, Draper W, Buenrostro JD, Litzenburger U, Cho SW, Satpathy AT, Carter AC, Ghosh RP, East-Seletsky A, et al. 2016 ATACsee reveals the accessible genome by transposase-mediated imaging and sequencing. Nature Methods 13 1013-1020. (https://doi. org/10.1038/nmeth.4031)

Chereji RV, Ocampo J \& Clark DJ 2017 MNase-sensitive complexes in yeast: nucleosomes and non-histone barriers. Molecular Cell 65565. e563-577.e563. (https://doi.org/10.1016/j.molcel.2016.12.009)

Chronis C, Fiziev P, Papp B, Butz S, Bonora G, Sabri S, Ernst J \& Plath K 2017 Cooperative binding of transcription factors orchestrates reprogramming. Cell 168 442.e420-459.e420. (https://doi. org/10.1016/j.cell.2016.12.016)

Cirillo LA, Lin FR, Cuesta I, Friedman D, Jarnik M \& Zaret KS 2002 Opening of compacted chromatin by early developmental transcription factors HNF3 (FoxA) and GATA-4. Molecular Cell 9 279-289. (https://doi.org/10.1016/S1097-2765(02)00459-8)

Cooper J, Ding Y, Song J \& Zhao K 2017 Genome-wide mapping of DNase I hypersensitive sites in rare cell populations using single-cell DNase sequencing. Nature Protocols 12 2342-2354. (https://doi. org/10.1038/nprot.2017.099)

Corces MR, Trevino AE, Hamilton EG, Greenside PG, SinnottArmstrong NA, Vesuna S, Satpathy AT, Rubin AJ, Montine KS, Wu B, et al. 2017 An improved ATAC-seq protocol reduces background and enables interrogation of frozen tissues. Nature Methods 14 959-962. (https://doi.org/10.1038/nmeth.4396)

Coulon A, Chow CC, Singer RH \& Larson DR 2013 Eukaryotic transcriptional dynamics: from single molecules to cell populations. Nature Reviews Genetics 14 572-584. (https://doi.org/10.1038/ $\operatorname{nrg} 3484)$

Creighton CJ, Kent Osborne C, van de Vijver MJ, Foekens JA, Klijn JG, Horlings HM, Nuyten D, Wang Y, Zhang Y, Chamness GC, et al. 2009 Molecular profiles of progesterone receptor loss in human breast tumors. Breast Cancer Research and Treatment 114 287-299. (https://doi.org/10.1007/s10549-008-0017-2)

D'Amato NC, Gordon MA, Babbs B, Spoelstra NS, Carson Butterfield KT, Torkko KC, Phan VT, Barton VN, Rogers TJ, Sartorius CA, et al. 2016 Cooperative dynamics of AR and ER activity in breast cancer. Molecular Cancer Research 14 1054-1067. (https://doi. org/10.1158/1541-7786.MCR-16-0167)

D'Antonio M, Weghorn D, D'Antonio-Chronowska A, Coulet F, Olson KM, DeBoever C, Drees F, Arias A, Alakus H, Richardson AL, et al. 2017 Identifying DNase I hypersensitive sites as driver distal regulatory elements in breast cancer. Nature Communications 8436 . (https://doi.org/10.1038/s41467-017-00100-x)

Daniel AR, Gaviglio AL, Knutson TP, Ostrander JH, D'Assoro AB, Ravindranathan P, Peng Y, Raj GV, Yee D \& Lange CA 2015 Progesterone receptor-B enhances estrogen responsiveness of breast cancer cells via scaffolding PELP1- and estrogen receptor-containing transcription complexes. Oncogene 34 506-515. (https://doi. org/10.1038/onc.2013.579)

Davies JO, Oudelaar AM, Higgs DR \& Hughes JR 2017 How best to identify chromosomal interactions: a comparison of approaches. Nature Methods 14 125-134. (https://doi.org/10.1038/nmeth.4146)

Dawson MA 2017 The cancer epigenome: concepts, challenges, and therapeutic opportunities. Science 355 1147-1152. (https://doi. org/10.1126/science.aam7304)

Dekker J, Rippe K, Dekker M \& Kleckner N 2002 Capturing chromosome conformation. Science 295 1306-1311. (https://doi.org/10.1126/ science.1067799)

Denny SK, Yang D, Chuang CH, Brady JJ, Lim JS, Gruner BM, Chiou SH, Schep AN, Baral J, Hamard C, et al. 2016 Nfib promotes metastasis through a widespread increase in chromatin accessibility. Cell 166 328-342. (https://doi.org/10.1016/j.cell.2016.05.052)

Donaghey J, Thakurela S, Charlton J, Chen JS, Smith ZD, Gu H, Pop R, Clement K, Stamenova EK, Karnik R, et al. 2018 Genetic determinants and epigenetic effects of pioneer-factor occupancy. Nature Genetics 50 250-258. (https://doi.org/10.1038/s41588-0170034-3)

Drouin J 2014 Minireview: pioneer transcription factors in cell fate specification. Molecular Endocrinology 28 989-998. (https://doi. org/10.1210/me.2014-1084)

Dubois-Chevalier J, Dubois V, Dehondt H, Mazrooei P, Mazuy C, Serandour AA, Gheeraert C, Guillaume P, Bauge E, Derudas B, et al. 2017 The logic of transcriptional regulator recruitment architecture at cis-regulatory modules controlling liver functions. Genome Research 27 985-996. (https://doi.org/10.1101/gr.217075.116)

Elf J, Li GW \& Xie XS 2007 Probing transcription factor dynamics at the single-molecule level in a living cell. Science 316 1191-1194. (https:// doi.org/10.1126/science.1141967)

Enuka Y, Feldman ME, Chowdhury A, Srivastava S, Lindzen M, SasChen A, Massart R, Cheishvili D, Suderman MJ, Zaltsman Y, et al. 
2017 Epigenetic mechanisms underlie the crosstalk between growth factors and a steroid hormone. Nucleic Acids Research $\mathbf{4 5}$ 12681-12699. (https://doi.org/10.1093/nar/gkx865)

Finlay-Schultz J, Gillen AE, Brechbuhl HM, Ivie JJ, Matthews SB, Jacobsen BM, Bentley DL, Kabos P \& Sartorius CA 2017 Breast cancer suppression by progesterone receptors is mediated by their modulation of estrogen receptors and RNA polymerase III. Cancer Research 77 4934-4946. (https://doi.org/10.1158/1538-7445.AM20174934)

Franco HL, Nagari A \& Kraus WL 2015 TNFalpha signaling exposes latent estrogen receptor binding sites to alter the breast cancer cell transcriptome. Molecular Cell 58 21-34. (https://doi.org/10.1016/j. molcel.2015.02.001)

Fullwood MJ, Liu MH, Pan YF, Liu J, Xu H, Mohamed YB, Orlov YL, Velkov S, Ho A, Mei PH, et al. 2009 An oestrogen-receptor-alphabound human chromatin interactome. Nature 462 58-64. (https:// doi.org/10.1038/nature08497)

Furey TS 2012 ChIP-seq and beyond: new and improved methodologies to detect and characterize protein-DNA interactions. Nature Reviews Genetics 13 840-852. (https://doi.org/10.1038/nrg3306)

Galas DJ \& Schmitz A 1978 DNAse footprinting: a simple method for the detection of protein-DNA binding specificity. Nucleic Acids Research 5 3157-3170. (https://doi.org/10.1093/nar/5.9.3157)

Garreau JR, Muller P, Pommier R \& Pommier S 2006 Transgenic introduction of androgen receptor into estrogen-receptor-, progesterone-receptor-, and androgen-receptor-negative breast cancer cells renders them responsive to hormonal manipulation. American Journal of Surgery 191 576-580. (https://doi.org/10.1016/j. amjsurg.2006.02.004)

Gaulton K, Nammo T, Pasquali L, Simon J, Giresi PG, Fogarty M, Panhuis T, Mieczkowski P, Secchi A, Bosco D, et al. 2010 A map of open chromatin in human pancreatic islets. Nature Genetics 42 255-259. (https://doi.org/10.1038/ng.530)

Gautier A, Juillerat A, Heinis C, Correa IR Jr, Kindermann M, Beaufils F \& Johnsson K 2008 An engineered protein tag for multiprotein labeling in living cells. Chemistry and Biology 15 128-136. (https:// doi.org/10.1016/j.chembiol.2008.01.007)

Gebhardt JC, Suter DM, Roy R, Zhao ZW, Chapman AR, Basu S, Maniatis T \& Xie XS 2013 Single-molecule imaging of transcription factor binding to DNA in live mammalian cells. Nature Methods $\mathbf{1 0}$ 421-426. (https://doi.org/10.1038/nmeth.2411)

Gertz J, Savic D, Varley KE, Partridge EC, Safi A, Jain P, Cooper GM, Reddy TE, Crawford GE \& Myers RM 2013 Distinct properties of cell-type-specific and shared transcription factor binding sites. Molecular Cell 52 25-36. (https://doi.org/10.1016/j. molcel.2013.08.037)

Goldstein I, Baek S, Presman DM, Paakinaho V, Swinstead EE \& Hager GL 2017a Transcription factor assisted loading and enhancer dynamics dictate the hepatic fasting response. Genome Research $\mathbf{2 7}$ 427-439. (https://doi.org/10.1101/gr.212175.116)

Goldstein I, Paakinaho V, Baek S, Sung MH \& Hager GL 2017b Synergistic gene expression during the acute phase response is characterized by transcription factor assisted loading. Nature Communications 11849. (https://doi.org/10.1038/s41467-017-02055-5)

Greene GL, Gilna P, Waterfield M, Baker A, Hort Y \& Shine J 1986 Sequence and expression of human estrogen receptor complementary DNA. Science 231 1150-1154. (https://doi. org/10.1126/science.3753802)

Grimm JB, English BP, Chen J, Slaughter JP, Zhang Z, Revyakin A, Patel R, Macklin JJ, Normanno D, Singer RH, et al. 2015 A general method to improve fluorophores for live-cell and single-molecule microscopy. Nature Methods 12 244-250. (https://doi.org/10.1038/ nmeth.3256)

Grontved L, John S, Baek S, Liu Y, Buckley JR, Vinson C, Aguilera G \& Hager GL 2013 C/EBP maintains chromatin accessibility in liver and facilitates glucocorticoid receptor recruitment to steroid response elements. EMBO Journal 32 1568-1583. (https://doi.org/10.1038/ emboj.2013.106)

Grossman SR, Zhang X, Wang L, Engreitz J, Melnikov A, Rogov P, Tewhey R, Isakova A, Deplancke B, Bernstein BE, et al. 2017 Systematic dissection of genomic features determining transcription factor binding and enhancer function. PNAS 114 E1291-E1300. (https://doi.org/10.1073/pnas.1621150114)

Hager GL, McNally JG \& Misteli T 2009 Transcription dynamics. Molecular Cell 35 741-753. (https://doi.org/10.1016/j. molcel.2009.09.005)

Hansen AS, Pustova I, Cattoglio C, Tjian R \& Darzacq X 2017 CTCF and cohesin regulate chromatin loop stability with distinct dynamics. eLife 6 e25776. (https://doi.org/10.7554/eLife.25776)

He HH, Meyer CA, Chen MW, Jordan VC, Brown M \& Liu XS 2012 Differential DNase I hypersensitivity reveals factor-dependent chromatin dynamics. Genome Research 22 1015-1025. (https://doi. org/10.1101/gr.133280.111)

He HH, Meyer CA, Hu SS, Chen MW, Zang C, Liu Y, Rao PK, Fei T, $\mathrm{Xu} \mathrm{H}$, Long $\mathrm{H}$, et al. 2014 Refined DNase-seq protocol and data analysis reveals intrinsic bias in transcription factor footprint identification. Nature Methods 11 73-78. (https://doi.org/10.1038/ nmeth.2762)

Hegde SM, Kumar MN, Kavya K, Kumar KM, Nagesh R, Patil RH, Babu RL, Ramesh GT \& Sharma SC 2016 Interplay of nuclear receptors (ER, PR, and GR) and their steroid hormones in MCF-7 cells. Molecular and Cellular Biochemistry 422 109-120. (https://doi. org/10.1007/s11010-016-2810-2)

Heinz S, Benner C, Spann N, Bertolino E, Lin YC, Laslo P, Cheng JX, Murre C, Singh H \& Glass CK 2010 Simple combinations of lineagedetermining transcription factors prime cis-regulatory elements required for macrophage and B cell identities. Molecular Cell $\mathbf{3 8}$ 576-589. (https://doi.org/10.1016/j.molcel.2010.05.004)

Heinz S, Romanoski CE, Benner C \& Glass CK 2015 The selection and function of cell type-specific enhancers. Nature Reviews Molecular Cell Biology 16 144-154. (https://doi.org/10.1038/nrm3949)

Honma N, Horii R, Iwase T, Saji S, Younes M, Ito Y \& Akiyama F 2012 Clinical importance of androgen receptor in breast cancer patients treated with adjuvant tamoxifen monotherapy. Breast Cancer 20 323-330. (https://doi.org/10.1007/s12282-012-0337-2)

Hu R, Dawood S, Holmes MD, Collins LC, Schnitt SJ, Cole K, Marotti JD, Hankinson SE, Colditz GA \& Tamimi RM 2011 Androgen receptor expression and breast cancer survival in postmenopausal women. Clinical Cancer Research 17 1867-1874. (https://doi. org/10.1158/1078-0432.CCR-10-2021)

Hurtado A, Holmes KA, Ross-Innes CS, Schmidt D \& Carroll JS 2010 FOXA1 is a key determinant of estrogen receptor function and endocrine response. Nature Genetics 43 27-33. (https://doi. org/10.1038/ng.730)

Illendula A, Pulikkan JA, Zong H, Grembecka J, Xue L, Sen S, Zhou Y, Boulton A, Kuntimaddi A, Gao Y, et al. 2015 A small-molecule inhibitor of the aberrant transcription factor CBF+Ý-SMMHC delays leukemia in mice. Science $\mathbf{3 4 7}$ 779-784. (https://doi.org/10.1126/ science.aaa0314)

Iwafuchi-Doi M, Donahue G, Kakumanu A, Watts JA, Mahony S, Pugh BF, Lee D, Kaestner KH \& Zaret KS 2016 The pioneer transcription factor FoxA maintains an accessible nucleosome configuration at enhancers for tissue-specific gene activation. Molecular Cell 62 79-91. (https://doi.org/10.1016/j. molcel.2016.03.001)

Izeddin I, Recamier V, Bosanac L, Cisse II, Boudarene L, DugastDarzacq C, Proux F, Benichou O, Voituriez R, Bensaude O, et al. 2014 Single-molecule tracking in live cells reveals distinct target-search strategies of transcription factors in the nucleus. eLife $\mathbf{3}$ e02230. (https://doi.org/10.7554/eLife.02230)

Jain D, Baldi S, Zabel A, Straub T \& Becker PB 2015 Active promoters give rise to false positive 'Phantom Peaks' in ChIP-seq experiments.
2018 Society for Endocrinology Published by Bioscientifica Ltd. Printed in Great Britain 
Nucleic Acids Research 43 6959-6968. (https://doi.org/10.1093/nar/ gkv637)

Javierre BM, Burren OS, Wilder SP, Kreuzhuber R, Hill SM, Sewitz S, Cairns J, Wingett SW, Varnai C, Thiecke MJ, et al. 2016 Lineagespecific genome architecture links enhancers and non-coding disease variants to target gene promoters. Cell 167 1369.e1319-1384.e1319. (https://doi.org/10.1016/j.cell.2016.09.037)

Jensen EV \& DeSombre ER 1973 Estrogen-receptor interaction. Science 182 126-134. (https://doi.org/10.1126/science.182.4108.126)

Jeselsohn R, Buchwalter G, De Angelis C, Brown M \& Schiff R 2015 ESR1 mutations-a mechanism for acquired endocrine resistance in breast cancer. Nature Reviews Clinical Oncology 12 573-583. (https:// doi.org/10.1038/nrclinonc.2015.117)

Jeselsohn R, Bergholz JS, Pun M, Cornwell M, Liu W, Nardone A, Xiao T, Li W, Qiu X, Buchwalter G, et al. 2018 Allele-specific chromatin recruitment and therapeutic vulnerabilities of ESR1 activating mutations. Cancer Cell 33 173.e175-186.e175. (https://doi. org/10.1016/j.ccell.2018.01.004)

Jin W, Tang Q, Wan M, Cui K, Zhang Y, Ren G, Ni B, Sklar J, Przytycka TM, Childs R, et al. 2015 Genome-wide detection of DNase I hypersensitive sites in single cells and FFPE tissue samples. Nature 528 142-146. (https://doi.org/10.1038/nature15740)

John S, Sabo PJ, Thurman RE, Sung MH, Biddie SC, Johnson TA, Hager GL \& Stamatoyannopoulos JA 2011 Chromatin accessibility pre-determines glucocorticoid receptor binding patterns. Nature Genetics 43 264-268. (https://doi.org/10.1038/ng.759)

Johnson DS, Mortazavi A, Myers RM \& Wold B 2007 Genome-wide mapping of in vivo protein-DNA interactions. Science $\mathbf{3 1 6}$ 1497-1502. (https://doi.org/10.1126/science.1141319)

Johnson TA, Chereji RV, Stavreva DA, Morris SA, Hager GL \& Clark DJ 2018 Conventional and pioneer modes of glucocorticoid receptor interaction with enhancer chromatin in vivo. Nucleic Acids Research 46 203-214. (https://doi.org/10.1093/nar/gkx1044)

Jolma A, Yin Y, Nitta KR, Dave K, Popov A, Taipale M, Enge M, Kivioja T, Morgunova E \& Taipale J 2015 DNA-dependent formation of transcription factor pairs alters their binding specificity. Nature 527 384-388. (https://doi.org/10.1038/nature15518)

Jordan VC 2015 The new biology of estrogen-induced apoptosis applied to treat and prevent breast cancer. Endocrine-Related Cancer 22 R1-R31. (https://doi.org/10.1530/ERC-14-0448)

Kadoch C, Williams RT, Calarco JP, Miller EL, Weber CM, Braun SM, Pulice JL, Chory EJ \& Crabtree GR 2017 Dynamics of BAF-Polycomb complex opposition on heterochromatin in normal and oncogenic states. Nature Genetics 49 213-222. (https://doi.org/10.1038/ng.3734)

Kaikkonen MU, Spann NJ, Heinz S, Romanoski CE, Allison KA, Stender JD, Chun HB, Tough DF, Prinjha RK, Benner C, et al. 2013 Remodeling of the enhancer landscape during macrophage activation is coupled to enhancer transcription. Molecular Cell $\mathbf{5 1}$ 310-325. (https://doi.org/10.1016/j.molcel.2013.07.010)

Karpova TS, Kim MJ, Spriet C, Nalley K, Stasevich TJ, Kherrouche Z, Heliot L \& McNally JG 2008 Concurrent fast and slow cycling of a transcriptional activator at an endogenous promoter. Science 319 466-469. (https://doi.org/10.1126/science.1150559)

Keene MA, Corces V, Lowenhaupt K \& Elgin SC 1981 DNase I hypersensitive sites in Drosophila chromatin occur at the $5^{\prime}$ ends of regions of transcription. PNAS $\mathbf{7 8} 143-146$. (https://doi.org/10.1073/ pnas.78.1.143)

Kieffer-Kwon K-R, Nimura K, Rao SSP, Xu J, Jung S, Pekowska A, Dose M, Stevens E, Mathe E, Dong P, et al. 2017 Myc regulates chromatin decompaction and nuclear architecture during B cell activation. Molecular Cell 67 566.e510-578.e510. (https://doi.org/10.1016/j. molcel.2017.07.013)

Kilic S, Bachmann AL, Bryan LC \& Fierz B 2015 Multivalency governs HP1alpha association dynamics with the silent chromatin state. Nature Communications 6 7313. (https://doi.org/10.1038/ ncomms8313)
Kim KH \& Roberts CW 2016 Targeting EZH2 in cancer. Nature Medicine 22 128-134. (https://doi.org/10.1038/nm.4036)

King HW \& Klose RJ 2017 The pioneer factor OCT4 requires the chromatin remodeller BRG1 to support gene regulatory element function in mouse embryonic stem cells. eLife 6 e22631. (https://doi. org/10.7554/eLife.22631)

Kittler R, Zhou J, Hua S, Ma L, Liu Y, Pendleton E, Cheng C, Gerstein M \& White KP 2013 A comprehensive nuclear receptor network for breast cancer cells. Cell Reports 3 538-551. (https://doi.org/10.1016/j. celrep.2013.01.004)

Lai WKM \& Pugh BF 2017 Understanding nucleosome dynamics and their links to gene expression and DNA replication. Nature Reviews Molecular Cell Biology 18 548-562. (https://doi.org/10.1038/nrm.2017.47)

Langlais D, Couture C, Balsalobre A \& Drouin J 2012 The Stat3/GR interaction code: predictive value of direct/indirect DNA recruitment for transcription outcome. Molecular Cell 47 38-49. (https://doi. org/10.1016/j.molcel.2012.04.021)

Lasko LM, Jakob CG, Edalji RP, Qiu W, Montgomery D, Digiammarino EL, Hansen TM, Risi RM, Frey R, Manaves V, et al. 2017 Discovery of a selective catalytic p300/CBP inhibitor that targets lineage-specific tumours. Nature 550 128-132. (https://doi. org/10.1038/nature24028)

Lazar MA 2017 Maturing of the nuclear receptor family. Journal of Clinical Investigation 127 1123-1125. (https://doi.org/10.1172/ JCI92949)

Li G, Fullwood MJ, Xu H, Mulawadi FH, Velkov S, Vega V, Ariyaratne PN, Mohamed YB, Ooi HS, Tennakoon C, et al. 2010 ChIA-PET tool for comprehensive chromatin interaction analysis with paired-end tag sequencing. Genome Biology 11 R22. (https://doi. org/10.1186/gb-2010-11-2-r22)

Li G, Ruan X, Auerbach RK, Sandhu KS, Zheng M, Wang P, Poh HM, Goh Y, Lim J, Zhang J, et al. 2012 Extensive promoter-centered chromatin interactions provide a topological basis for transcription regulation. Cell 148 84-98. (https://doi.org/10.1016/j. cell.2011.12.014)

Li M, Hada A, Sen P, Olufemi L, Hall MA, Smith BY, Forth S, McKnight JN, Patel A, Bowman GD, et al. 2015 Dynamic regulation of transcription factors by nucleosome remodeling. eLife $\mathbf{4}$ e06249. (https://doi.org/10.7554/eLife.05322)

Lieberman-Aiden E, van Berkum NL, Williams L, Imakaev M, Ragoczy T, Telling A, Amit I, Lajoie BR, Sabo PJ, Dorschner MO, et al. 2009 Comprehensive mapping of long-range interactions reveals folding principles of the human genome. Science 326 289-293. (https://doi. org/10.1126/science.1181369)

Lin Fde M, Pincerato KM, Bacchi CE, Baracat EC \& Carvalho FM 2012 Coordinated expression of oestrogen and androgen receptors in HER2-positive breast carcinomas: impact on proliferative activity. Journal of Clinical Pathology 65 64-68. (https://doi.org/10.1136/ jclinpath-2011-200318)

Liu Z \& Tjian R 2018 Visualizing transcription factor dynamics in living cells. Journal of Cell Biology 217 1181-1191. (https://doi.org/10.1083/ jcb.201710038)

Liu Z, Lavis LD \& Betzig E 2015 Imaging live-cell dynamics and structure at the single-molecule level. Molecular Cell 58 644-659. (https://doi.org/10.1016/j.molcel.2015.02.033)

Loffreda A, Jacchetti E, Antunes S, Rainone P, Daniele T, Morisaki T, Bianchi ME, Tacchetti C \& Mazza D 2017 Live-cell p53 singlemolecule binding is modulated by C-terminal acetylation and correlates with transcriptional activity. Nature Communications 8313. (https://doi.org/10.1038/s41467-017-00398-7)

Lonard DM \& O'Malley BW 2016 Molecular pathways: targeting steroid receptor coactivators in cancer. Clinical Cancer Research 22 5403-5407. (https://doi.org/10.1158/1078-0432.CCR-15-1958)

Long HK, Prescott SL \& Wysocka J 2016 Ever-changing landscapes: transcriptional enhancers in development and evolution. Cell 167 1170-1187. (https://doi.org/10.1016/j.cell.2016.09.018) 
Los GV, Encell LP, McDougall MG, Hartzell DD, Karassina N, Zimprich C, Wood MG, Learish R, Ohana RF, Urh M, et al. 2008 HaloTag: a novel protein labeling technology for cell imaging and protein analysis. ACS Chemical Biology 3 373-382. (https://doi. org/10.1021/cb800025k)

Lupien M \& Brown M 2009 Cistromics of hormone-dependent cancer Endocrine-Related Cancer 16 381-389. (https://doi.org/10.1677/ERC09-0038)

Lupien M, Eeckhoute J, Meyer CA, Wang Q, Zhang Y, Li W, Carroll JS, Liu XS \& Brown M 2008 FoxA1 translates epigenetic signatures into enhancer-driven lineage-specific transcription. Cell 132 958-970. (https://doi.org/10.1016/j.cell.2008.01.018)

Lupien M, Meyer CA, Bailey ST, Eeckhoute J, Cook J, Westerling T, Zhang X, Carroll JS, Rhodes DR, Liu XS, et al. 2010 Growth factor stimulation induces a distinct $\mathrm{ER}($ alpha) cistrome underlying breast cancer endocrine resistance. Genes and Development 24 2219-2227. (https://doi.org/10.1101/gad.1944810)

Madsen MS, Siersbaek R, Boergesen M, Nielsen R \& Mandrup S 2014 Peroxisome proliferator-activated receptor gamma and C/EBPalpha synergistically activate key metabolic adipocyte genes by assisted loading. Molecular and Cellular Biology 34 939-954. (https://doi. org/10.1128/MCB.01344-13)

Mangelsdorf DJ, Thummel C, Beato M, Herrlich P, Schutz G, Umesono K, Blumberg B, Kastner P, Mark M, Chambon P, et al. 1995 The nuclear receptor superfamily: the second decade. Cell $\mathbf{8 3}$ 835-839. (https://doi.org/10.1016/0092-8674(95)90199-X)

Manzo C \& Garcia-Parajo MF 2015 A review of progress in single particle tracking: from methods to biophysical insights. Reports on Progress in Physics 78 124601. (https://doi.org/10.1088/0034$4885 / 78 / 12 / 124601)$

Martin LA, Ribas R, Simigdala N, Schuster E, Pancholi S, Tenev T, Gellert P, Buluwela L, Harrod A, Thornhill A, et al. 2017 Discovery of naturally occurring ESR1 mutations in breast cancer cell lines modelling endocrine resistance. Nature Communications 81865. (https://doi.org/10.1038/s41467-017-01864-y)

Massie CE \& Mills IG 2008 ChIPping away at gene regulation. EMBO Reports 9 337-343. (https://doi.org/10.1038/embor.2008.44)

Maston GA, Landt SG, Snyder M \& Green MR 2012 Characterization of enhancer function from genome-wide analyses. Annual Review of Genomics and Human Genetics 13 29-57. (https://doi.org/10.1146/ annurev-genom-090711-163723)

Mauvais-Jarvis P, Kuttenn F, Malet C \& Gompel A 1990 Normal breast cells in culture. Effect of estrogens, progestins, and antiestrogens. Annals of the New York Academy of Sciences 595 117-129. (https://doi. org/10.1111/j.1749-6632.1990.tb34287.x)

Mayran A, Khetchoumian K, Hariri F, Pastinen T, Gauthier Y, Balsalobre A \& Drouin J 2018 Pioneer factor Pax7 deploys a stable enhancer repertoire for specification of cell fate. Nature Genetics $\mathbf{5 0}$ 259-269. (https://doi.org/10.1038/s41588-017-0035-2)

Mazza D, Abernathy A, Golob N, Morisaki T \& McNally JG 2012 A benchmark for chromatin binding measurements in live cells. Nucleic Acids Research 40 e119. (https://doi.org/10.1093/nar/gks701)

McGhee JD, Wood WI, Dolan M, Engel JD \& Felsenfeld G 1981 A 200 base pair region at the $5^{\prime}$ end of the chicken adult beta- globin gene is accessible to nuclease digestion. Cell 27 45-55. (https://doi. org/10.1016/0092-8674(81)90359-7)

McGuire WL 1978 Hormone receptors: their role in predicting prognosis and response to endocrine therapy. Seminars in Oncology 5 428-433.

McNally JG, Mueller WG, Walker D, Wolford RG \& Hager GL 2000 The glucocorticoid receptor: rapid exchange with regulatory sites in living cells. Science 287 1262-1265. (https://doi.org/10.1126/ science.287.5456.1262)

Miranda TB, Voss TC, Sung MH, Baek S, John S, Hawkins M, Grontved L, Schiltz RL \& Hager GL 2013 Reprogramming of the chromatin landscape: interplay of the estrogen and glucocorticoid receptors at the genomic level. Cancer Research 73 5130-5139. (https://doi.org/10.1158/0008-5472.CAN-13-0742)

Mohammed H, D'Santos C, Serandour AA, Ali HR, Brown GD, Atkins A, Rueda OM, Holmes KA, Theodorou V, Robinson JL, et al. 2013 Endogenous purification reveals GREB1 as a key estrogen receptor regulatory factor. Cell Reports 3 342-349. (https://doi.org/10.1016/j. celrep.2013.01.010)

Mohammed H, Russell IA, Stark R, Rueda OM, Hickey TE, Tarulli GA, Serandour AA, Birrell SN, Bruna A, Saadi A, et al. 2015 Progesterone receptor modulates ERalpha action in breast cancer. Nature $\mathbf{5 2 3}$ 313-317. (https://doi.org/10.1038/nature14583)

Morgunova E \& Taipale J 2017 Structural perspective of cooperative transcription factor binding. Current Opinion in Structural Biology $\mathbf{4 7}$ 1-8. (https://doi.org/10.1016/j.sbi.2017.03.006)

Morisaki T, Muller WG, Golob N, Mazza D \& McNally JG 2014 Singlemolecule analysis of transcription factor binding at transcription sites in live cells. Nature Communications 5 4456. (https://doi. org/10.1038/ncomms5456)

Mouridsen H, Gershanovich M, Sun Y, Perez-Carrion R, Boni C, Monnier A, Apffelstaedt J, Smith R, Sleeboom HP, Jaenicke F, et al. 2003 Phase III study of letrozole versus tamoxifen as first-line therapy of advanced breast cancer in postmenopausal women: analysis of survival and update of efficacy from the International Letrozole Breast Cancer Group. Journal of Clinical Oncology 21 2101-2109. (https://doi.org/10.1200/JCO.2003.04.194)

Mueller F, Stasevich TJ, Mazza D \& McNally JG 2013 Quantifying transcription factor kinetics: at work or at play? Critical Reviews in Biochemistry and Molecular Biology 48 492-514. (https://doi.org/10.31 09/10409238.2013.833891)

Murakami S, Nagari A \& Kraus WL 2017 Dynamic assembly and activation of estrogen receptor alpha enhancers through coregulator switching. Genes and Development 31 1535-1548. (https://doi. org/10.1101/gad.302182.117)

Nagaich AK, Walker DA, Wolford RG \& Hager GL 2004 Rapid periodic binding and displacement of the glucocorticoid receptor during chromatin remodeling. Molecular Cell 14 163-174. (https://doi. org/10.1016/S1097-2765(04)00178-9)

Neph S, Vierstra J, Stergachis AB, Reynolds AP, Haugen E, Vernot B, Thurman RE, John S, Sandstrom R, Johnson AK, et al. 2012 An expansive human regulatory lexicon encoded in transcription factor footprints. Nature 489 83-90. (https://doi.org/10.1038/nature11212)

Oh KS, Patel H, Gottschalk RA, Lee WS, Baek S, Fraser IDC, Hager GL \& Sung MH 2017 Anti-inflammatory chromatinscape suggests alternative mechanisms of glucocorticoid receptor action. Immunity 47 298.e295-309.e295. (https://doi.org/10.1016/j. immuni.2017.07.012)

Orlando V \& Paro R 1993 Mapping Polycomb-repressed domains in the bithorax complex using in vivo formaldehyde cross-linked chromatin. Cell 75 1187-1198. (https://doi.org/10.1016/00928674(93)90328-N)

Paakinaho V, Kaikkonen S, Makkonen H, Benes V \& Palvimo JJ 2014 SUMOylation regulates the chromatin occupancy and antiproliferative gene programs of glucocorticoid receptor. Nucleic Acids Research 42 1575-1592. (https://doi.org/10.1093/nar/gkt1033)

Paakinaho V, Presman DM, Ball DA, Johnson TA, Schiltz RL, Levitt P, Mazza D, Morisaki T, Karpova TS \& Hager GL 2017 Single-molecule analysis of steroid receptor and cofactor action in living cells. Nature Communications 8 15896. (https://doi.org/10.1038/ncomms15896)

Pan D, Kocherginsky M \& Conzen SD 2011 Activation of the glucocorticoid receptor is associated with poor prognosis in estrogen receptor-negative breast cancer. Cancer Research 71 6360-6370. (https://doi.org/10.1158/0008-5472.CAN-11-0362)

Perissi V \& Rosenfeld MG 2005 Controlling nuclear receptors: the circular logic of cofactor cycles. Nature Reviews Molecular Cell Biology 6 542-554. (https://doi.org/10.1038/nrm1680) (c) 2018 Society for Endocrinology Published by Bioscientifica Ltd. Printed in Great Britain 
Petta I, Dejager L, Ballegeer M, Lievens S, Tavernier J, De Bosscher K \& Libert C 2016 The interactome of the glucocorticoid receptor and its influence on the actions of glucocorticoids in combatting inflammatory and infectious diseases. Microbiology and Molecular Biology Reviews 80 495-522. (https://doi.org/10.1128/MMBR.00064-15)

Presman DM, Ball DA, Paakinaho V, Grimm JB, Lavis LD, Karpova TA \& Hager GL 2017 Quantifying transcription factor dynamics at the single-molecule level in live cells. Methods 123 76-88. (https://doi. org/10.1016/j.ymeth.2017.03.014)

Pulice JL \& Kadoch C 2016 Composition and function of mammalian SWI/SNF chromatin remodeling complexes in human disease. Cold Spring Harbor Symposia on Quantitative Biology 81 53-60. (https://doi. org/10.1101/sqb.2016.81.031021)

Qi JP, Yang YL, Zhu H, Wang J, Jia Y, Liu N, Song YJ, Zan LK, Zhang X, Zhou M, et al. 2012 Expression of the androgen receptor and its correlation with molecular subtypes in 980 chinese breast cancer patients. Breast Cancer 6 1-8. (https://doi.org/10.4137/BCBCR.S8323)

Qu K, Zaba LC, Satpathy AT, Giresi PG, Li R, Jin Y, Armstrong R, Jin C, Schmitt N, Rahbar Z, et al. 2017 Chromatin accessibility landscape of cutaneous $\mathrm{T}$ cell lymphoma and dynamic response to HDAC inhibitors. Cancer Cell 32 27.e24-41.e24. (https://doi.org/10.1016/j. ccell.2017.05.008)

Rafiee MR, Girardot C, Sigismondo G \& Krijgsveld J 2016 Expanding the circuitry of pluripotency by selective isolation of chromatinassociated proteins. Molecular Cell 64 624-635. (https://doi. org/10.1016/j.molcel.2016.09.019)

Rao SS, Huntley MH, Durand NC, Stamenova EK, Bochkov ID, Robinson JT, Sanborn AL, Machol I, Omer AD, Lander ES, et al. 2014 A 3D map of the human genome at kilobase resolution reveals principles of chromatin looping. Cell 159 1665-1680. (https://doi. org/10.1016/j.cell.2014.11.021)

Rechoum Y, Rovito D, Iacopetta D, Barone I, Ando S, Weigel NL, O'Malley BW, Brown PH \& Fuqua SA 2014 AR collaborates with ERalpha in aromatase inhibitor-resistant breast cancer. Breast Cancer Research and Treatment 147 473-485. (https://doi.org/10.1007/ s10549-014-3082-8)

Rhee HS \& Pugh BF 2011 Comprehensive genome-wide protein-DNA interactions detected at single-nucleotide resolution. Cell $\mathbf{1 4 7}$ 1408-1419. (https://doi.org/10.1016/j.cell.2011.11.013)

Rheinbay E, Parasuraman P, Grimsby J, Tiao G, Engreitz JM, Kim J, Lawrence MS, Taylor-Weiner A, Rodriguez-Cuevas S, Rosenberg M, et al. 2017 Recurrent and functional regulatory mutations in breast cancer. Nature 547 55-60. (https://doi.org/10.1038/nature22992)

Ribich S, Harvey D \& Copeland RA 2017 Drug discovery and chemical biology of cancer epigenetics. Cell Chemical Biology 24 1120-1147. (https://doi.org/10.1016/j.chembiol.2017.08.020)

Risca VI, Denny SK, Straight AF \& Greenleaf WJ 2017 Variable chromatin structure revealed by in situ spatially correlated DNA cleavage mapping. Nature 541 237-241. (https://doi.org/10.1038/ nature20781)

Robertson G, Hirst M, Bainbridge M, Bilenky M, Zhao Y, Zeng T, Euskirchen G, Bernier B, Varhol R, Delaney A, et al. 2007 Genomewide profiles of STAT1 DNA association using chromatin immunoprecipitation and massively parallel sequencing. Nature Methods 4 651-657. (https://doi.org/10.1038/nmeth1068)

Robinson JL, MacArthur S, Ross-Innes CS, Tilley WD, Neal DE, Mills IG \& Carroll JS 2011 Androgen receptor driven transcription in molecular apocrine breast cancer is mediated by FoxA1. EMBO Journal 30 3019-3027. (https://doi.org/10.1038/emboj.2011.216)

Roe JS, Hwang CI, Somerville TDD, Milazzo JP, Lee EJ, Da Silva B, Maiorino L, Tiriac H, Young CM, Miyabayashi K, et al. 2017 Enhancer reprogramming promotes pancreatic cancer metastasis. Cell 170 875.e820-888.e820. (https://doi.org/10.1016/j. cell.2017.07.007)

Rosa FE, Caldeira JR, Felipes J, Bertonha FB, Quevedo FC, Domingues MA, Moraes Neto FA \& Rogatto SR 2008 Evaluation of estrogen receptor alpha and beta and progesterone receptor expression and correlation with clinicopathologic factors and proliferative marker Ki-67 in breast cancers. Human Pathology 39 720-730. (https://doi.org/10.1016/j.humpath.2007.09.019)

Roses DF 1999 Breast Cancer. London, UK: Churchill Livingstone.

Rossouw JE, Anderson GL, Prentice RL, LaCroix AZ, Kooperberg C, Stefanick ML, Jackson RD, Beresford SA, Howard BV, Johnson KC, et al. 2002 Risks and benefits of estrogen plus progestin in healthy postmenopausal women: principal results From the Women's Health Initiative randomized controlled trial. JAMA 288 321-333. (https:// doi.org/10.1001/jama.288.3.321)

Rotem A, Ram O, Shoresh N, Sperling RA, Goren A, Weitz DA \& Bernstein BE 2015 Single-cell ChIP-seq reveals cell subpopulations defined by chromatin state. Nature Biotechnology 33 1165-1172. (https://doi.org/10.1038/nbt.3383)

Sahu B, Laakso M, Ovaska K, Mirtti T, Lundin J, Rannikko A, Sankila A Turunen JP, Lundin M, Konsti J, et al. 2011 Dual role of FoxA1 in androgen receptor binding to chromatin, androgen signalling and prostate cancer. EMBO Journal 30 3962-3976. (https://doi. org/10.1038/emboj.2011.328)

Santen RJ 2014 Menopausal hormone therapy and breast cancer. Journal of Steroid Biochemistry and Molecular Biology 142 52-61. (https://doi. org/10.1016/j.jsbmb.2013.06.010)

Schaffner W 2015 Enhancers, enhancers - from their discovery to today's universe of transcription enhancers. Biological Chemistry 396 311-327. (https://doi.org/10.1515/hsz-2014-030)

Schmidt JC, Zaug AJ \& Cech TR 2016 Live cell imaging reveals the dynamics of telomerase recruitment to telomeres. Cell 166 1188-1197. (https://doi.org/10.1016/j.cell.2016.07.033)

Schoenfelder S, Furlan-Magaril M, Mifsud B, Tavares-Cadete F, Sugar R, Javierre BM, Nagano T, Katsman Y, Sakthidevi M, Wingett SW, et al. 2015 The pluripotent regulatory circuitry connecting promoters to their long-range interacting elements. Genome Research 25 582-597. (https://doi.org/10.1101/gr.185272.114)

Schones DE, Cui K, Cuddapah S, Roh TY, Barski A, Wang Z, Wei G \& Zhao K 2008 Dynamic regulation of nucleosome positioning in the human genome. Cell 132 887-898. (https://doi.org/10.1016/j. cell.2008.02.022)

Severson TM, Kim Y, Joosten SEP, Schuurman K, van der Groep P, Moelans CB, Ter Hoeve ND, Manson QF, Martens JW, van Deurzen CHM, et al. 2018 Characterizing steroid hormone receptor chromatin binding landscapes in male and female breast cancer. Nature Communications 9 482. (https://doi.org/10.1038/s41467-018-02856-2)

Siegel R, Ward E, Brawley O \& Jemal A 2011 Cancer statistics, 2011: the impact of eliminating socioeconomic and racial disparities on premature cancer deaths. CA: A Cancer Journal for Clinicians 61 212-236. (https://doi.org/10.3322/caac.20121)

Siersbaek R, Baek S, Rabiee A, Nielsen R, Traynor S, Clark N, Sandelin A Jensen ON, Sung MH, Hager GL, et al. 2014 Molecular architecture of transcription factor hotspots in early adipogenesis. Cell Reports $\mathbf{7}$ 1434-1442. (https://doi.org/10.1016/j.celrep.2014.04.043)

Singhal H, Greene ME, Tarulli G, Zarnke AL, Bourgo RJ, Laine M, Chang YF, Ma S, Dembo AG, Raj GV, et al. 2016 Genomic agonism and phenotypic antagonism between estrogen and progesterone receptors in breast cancer. Science Advances 2 e1501924. (https://doi. org/10.1126/sciadv.1501924)

Singhal H, Greene ME, Zarnke AL, Laine M, Al Abosy R, Chang YF, Dembo AG, Schoenfelt K, Vadhi R, Qiu X, et al. 2018 Progesterone receptor isoforms, agonists and antagonists differentially reprogram estrogen signaling. Oncotarget 9 4282-4300. (https://doi. org/10.18632/oncotarget.21378)

Smith E \& Shilatifard A 2014 Enhancer biology and enhanceropathies. Nature Structural and Molecular Biology 21 210-219. (https://doi. org/10.1038/nsmb.2784)

Soccio RE, Chen ER, Rajapurkar SR, Safabakhsh P, Marinis JM, Dispirito JR, Emmett MJ, Briggs ER, Fang B, Everett LJ, et al. 2015
(C) 2018 Society for Endocrinology Published by Bioscientifica Ltd. Printed in Great Britain 
Genetic variation determines PPARgamma function and anti-diabetic drug response in vivo. Cell 162 33-44. (https://doi.org/10.1016/j. cell.2015.06.025)

Solomon MJ, Larsen PL \& Varshavsky A 1988 Mapping protein-DNA interactions in vivo with formaldehyde: evidence that histone $\mathrm{H} 4$ is retained on a highly transcribed gene. Cell 53 937-947. (https://doi. org/10.1016/S0092-8674(88)90469-2)

Song L, Zhang Z, Grasfeder LL, Boyle AP, Giresi PG, Lee BK, Sheffield NC, Graf S, Huss M, Keefe D, et al. 2011 Open chromatin defined by DNaseI and FAIRE identifies regulatory elements that shape cell-type identity. Genome Research 21 1757-1767. (https://doi. org/10.1101/gr.121541.111)

Song X, Chen J, Zhao M, Zhang C, Yu Y, Lonard DM, Chow DC, Palzkill T, Xu J, O'Malley BW, et al. 2016 Development of potent small-molecule inhibitors to drug the undruggable steroid receptor coactivator-3. PNAS 113 4970-4975. (https://doi.org/10.1073/ pnas.1604274113)

Soon WW, Hariharan M \& Snyder MP 2013 High-throughput sequencing for biology and medicine. Molecular Systems Biology 9 640. (https://doi.org/10.1038/msb.2012.61)

Soufi A, Garcia MF, Jaroszewicz A, Osman N, Pellegrini M \& Zaret KS 2015 Pioneer transcription factors target partial DNA motifs on nucleosomes to initiate reprogramming. Cell 161 555-568. (https:// doi.org/10.1016/j.cell.2015.03.017)

Spitz F \& Furlong EE 2012 Transcription factors: from enhancer binding to developmental control. Nature Reviews Genetics 13 613-626. (https://doi.org/10.1038/nrg3207)

Starick SR, Ibn-Salem J, Jurk M, Hernandez C, Love MI, Chung HR, Vingron M, Thomas-Chollier M \& Meijsing SH 2015 ChIP-exo signal associated with DNA-binding motifs provide insights into the genomic binding of the glucocorticoid receptor and cooperating transcription factors. Genome Research 25 825-835. (https://doi. org/10.1101/gr.185157.114)

Stasevich TJ \& McNally JG 2011 Assembly of the transcription machinery: ordered and stable, random and dynamic, or both? Chromosoma 120 533-545. (https://doi.org/10.1007/s00412-0110340-y)

Stavreva DA, Muller WG, Hager GL, Smith CL \& McNally JG 2004 Rapid glucocorticoid receptor exchange at a promoter is coupled to transcription and regulated by chaperones and proteasomes. Molecular and Cellular Biology 24 2682-2697. (https://doi. org/10.1128/МСB.24.7.2682-2697.2004)

Stender JD, Kim K, Charn TH, Komm B, Chang KC, Kraus WL, Benner C, Glass CK \& Katzenellenbogen BS 2010 Genome-wide analysis of estrogen receptor alpha DNA binding and tethering mechanisms identifies Runx1 as a novel tethering factor in receptormediated transcriptional activation. Molecular and Cellular Biology 30 3943-3955. (https://doi.org/10.1128/MСB.00118-10)

Stender JD, Nwachukwu JC, Kastrati I, Kim Y, Strid T, Yakir M, Srinivasan S, Nowak J, Izard T, Rangarajan ES, et al. 2017 Structural and molecular mechanisms of cytokine-mediated endocrine resistance in human breast cancer cells. Molecular Cell 651122. e1125-1135.e1125. (https://doi.org/10.1016/j.molcel.2017.02.008)

Stenoien DL, Patel K, Mancini MG, Dutertre M, Smith CL, O'Malley BW \& Mancini MA 2001 FRAP reveals that mobility of oestrogen receptor-alpha is ligand- and proteasome-dependent. Nature Cell Biology 3 15-23. (https://doi.org/10.1038/35050515)

Stergachis AB, Neph S, Reynolds A, Humbert R, Miller B, Paige SL, Vernot B, Cheng JB, Thurman RE, Sandstrom R, et al. 2013 Developmental fate and cellular maturity encoded in human regulatory DNA landscapes. Cell 154 888-903. (https://doi. org/10.1016/j.cell.2013.07.020)

Stergachis AB, Neph S, Sandstrom R, Haugen E, Reynolds AP, Zhang M, Byron R, Canfield T, Stelhing-Sun S, Lee K, et al. 2014 Conservation of trans-acting circuitry during mammalian regulatory evolution. Nature 515 365-370. (https://doi.org/10.1038/nature13972)
Steube A, Schenk T, Tretyakov A \& Saluz HP 2017 High-intensity UV laser ChIP-seq for the study of protein-DNA interactions in living cells. Nature Communications 8 1303. (https://doi.org/10.1038/ s41467-017-01251-7)

Sugo N, Morimatsu M, Arai Y, Kousoku Y, Ohkuni A, Nomura T, Yanagida T \& Yamamoto N 2015 Single-molecule imaging reveals dynamics of CREB transcription factor bound to its target sequence. Scientific Reports 5 10662. (https://doi.org/10.1038/srep10662)

Sung MH, Guertin MJ, Baek S \& Hager GL 2014 DNase footprint signatures are dictated by factor dynamics and DNA sequence. Molecular Cell 56 275-285. (https://doi.org/10.1016/j. molcel.2014.08.016)

Sung M-H, Baek S \& Hager GL 2016 Genome-wide footprinting: ready for prime time? Nature Methods 13 222-228. (https://doi. org/10.1038/nmeth.3766)

Sur I \& Taipale J 2016 The role of enhancers in cancer. Nature Reviews Cancer 16 483-493. (https://doi.org/10.1038/nrc.2016.62)

Sur IK, Hallikas O, Vaharautio A, Yan J, Turunen M, Enge M, Taipale M, Karhu A, Aaltonen LA \& Taipale J 2012 Mice lacking a Myc enhancer that includes human SNP rs6983267 are resistant to intestinal tumors. Science 338 1360-1363. (https://doi.org/10.1126/ science.1228606)

Swinstead EE, Miranda TB, Paakinaho V, Baek S, Goldstein I, Hawkins M, Karpova TS, Ball DA, Mazza D, Lavis LD, et al. 2016a Steroid receptors reprogram FoxA1 occupancy through dynamic chromatin transitions. Cell 165 593-605. (https://doi.org/10.1016/j. cell.2016.02.067)

Swinstead EE, Paakinaho V, Presman DM \& Hager GL $2016 b$ Pioneer factors and ATP-dependent chromatin remodeling factors interact dynamically: a new perspective: multiple transcription factors can effect chromatin pioneer functions through dynamic interactions with ATP-dependent chromatin remodeling factors. Bioessays $\mathbf{3 8}$ 1150-1157. (https://doi.org/10.1002/bies.201600137)

Takahashi K \& Yamanaka S 2006 Induction of pluripotent stem cells from mouse embryonic and adult fibroblast cultures by defined factors. Cell 126 663-676. (https://doi.org/10.1016/j. cell.2006.07.024)

Takaku M, Grimm SA, Shimbo T, Perera L, Menafra R, Stunnenberg HG, Archer TK, Machida S, Kurumizaka H \& Wade PA 2016 GATA3dependent cellular reprogramming requires activation-domain dependent recruitment of a chromatin remodeler. Genome Biology 17 36. (https://doi.org/10.1186/s13059-016-0897-0)

Teves SS, An L, Hansen AS, Xie L, Darzacq X \& Tjian R 2016 A dynamic mode of mitotic bookmarking by transcription factors. eL ife $\mathbf{5}$ e22280. (https://doi.org/10.7554/eLife.22280)

Theodorou V, Stark R, Menon S \& Carroll JS 2012 GATA3 acts upstream of FOXA1 in mediating ESR1 binding by shaping enhancer accessibility. Genome Research 23 12-22. (https://doi.org/10.1101/ gr.139469.112)

Thurman RE, Rynes E, Humbert R, Vierstra J, Maurano MT, Haugen E, Sheffield NC, Stergachis AB, Wang H, Vernot B, et al. 2012 The accessible chromatin landscape of the human genome. Nature $\mathbf{4 8 9}$ 75-82. (https://doi.org/10.1038/nature11232)

Tokunaga M, Imamoto N \& Sakata-Sogawa K 2008 Highly inclined thin illumination enables clear single-molecule imaging in cells. Nature Methods 5 159-161. (https://doi.org/10.1038/nmeth1171)

Toy W, Weir H, Razavi P, Lawson M, Goeppert AU, Mazzola AM, Smith A, Wilson J, Morrow C, Wong WL, et al. 2017 Activating ESR1 mutations differentially affect the efficacy of ER antagonists. Cancer Discovery 7 277-287. (https://doi.org/10.1158/2159-8290.CD-151523)

Uhlenhaut NH, Barish GD, Yu RT, Downes M, Karunasiri M, Liddle C, Schwalie P, Hubner N \& Evans RM 2012 Insights into negative regulation by the glucocorticoid receptor from genome-wide profiling of inflammatory cistromes. Molecular Cell 49 158-171. (https://doi.org/10.1016/j.molcel.2012.10.013)
(C) 2018 Society for Endocrinology Published by Bioscientifica Ltd. Printed in Great Britain 
Vera M, Biswas J, Senecal A, Singer RH \& Park HY 2016 Single-cell and single-molecule analysis of gene expression regulation. Annual Review of Genetics $\mathbf{5 0}$ 267-291. (https://doi.org/10.1146/annurevgenet-120215-034854)

von Diezmann A, Shechtman Y \& Moerner WE 2017 Three-dimensional localization of single molecules for super-resolution imaging and single-particle tracking. Chemical Reviews 117 7244-7275. (https:// doi.org/10.1021/acs.chemrev.6b00629)

Voong LN, Xi L, Sebeson AC, Xiong B, Wang JP \& Wang X 2016 Insights into nucleosome organization in mouse embryonic stem cells through chemical mapping. Cell 167 1555.e1515-1570.e1515. (https://doi.org/10.1016/j.cell.2016.10.049)

Voong LN, Xi L, Wang JP \& Wang X 2017 Genome-wide mapping of the nucleosome landscape by micrococcal nuclease and chemical mapping. Trends in Genetics 33 495-507. (https://doi.org/10.1016/j. tig.2017.05.007)

Voss TC \& Hager GL 2014 Dynamic regulation of transcriptional states by chromatin and transcription factors. Nature Reviews Genetics $\mathbf{1 5}$ 69-81. (https://doi.org/10.1038/nrg3623)

Voss TC, Schiltz RL, Sung MH, Yen PM, Stamatoyannopoulos JA, Biddie SC, Johnson TA, Miranda TB, John S \& Hager GL 2011 Dynamic exchange at regulatory elements during chromatin remodeling underlies assisted loading mechanism. Cell 146 544-554. (https://doi.org/10.1016/j.cell.2011.07.006)

Walter P, Green S, Greene G, Krust A, Bornert JM, Jeltsch JM, Staub A, Jensen E, Scrace G, Waterfield M, et al. 1985 Cloning of the human estrogen receptor cDNA. PNAS 82 7889-7893. (https://doi org/10.1073/pnas.82.23.7889)

Welboren WJ, van Driel MA, Janssen-Megens EM, van Heeringen SJ, Sweep FC, Span PN \& Stunnenberg HG 2009 ChIP-Seq of ERalpha and RNA polymerase II defines genes differentially responding to ligands. EMBO Journal 28 1418-1428. (https://doi.org/10.1038/emboj.2009.88)

West DC, Pan D, Tonsing-Carter EY, Hernandez KM, Pierce CF, Styke SC, Bowie KR, Garcia TI, Kocherginsky M \& Conzen SD 2016 GR and ER co-activation alters the expression of differentiation genes and associates with improved ER+ breast cancer outcome. Molecular Cancer Research 14 707-719. (https://doi.org/10.1158/1541-7786. MCR-15-0433)

Wittliff JL 1984 Steroid-hormone receptors in breast cancer. Cancer 53 630-643. (https://doi.org/10.1002/1097-

0142(19840201)53:3+<630::AID-CNCR2820531308>3.0.CO;2-3)

Yang F, Ma Q, Liu Z, Li W, Tan Y, Jin C, Ma W, Hu Y, Shen J, Ohgi KA, et al. 2017 Glucocorticoid receptor: MegaTrans switching mediates the repression of an ERalpha-regulated transcriptional program. Molecular Cell 66 321.e326-331.e326. (https://doi.org/10.1016/j. molcel.2017.03.019)

Yi P, Wang Z, Feng Q, Chou CK, Pintilie GD, Shen H, Foulds CE, Fan G, Serysheva I, Ludtke SJ, et al. 2017 Structural and functional impacts of ER coactivator sequential recruitment. Molecular Cell 67 733.e734743.e734. (https://doi.org/10.1016/j.molcel.2017.07.026)

Zaret KS \& Carroll JS 2011 Pioneer transcription factors: establishing competence for gene expression. Genes and Development 25 2227-2241. (https://doi.org/10.1101/gad.176826.111)

Zaret KS \& Mango SE 2016 Pioneer transcription factors, chromatin dynamics, and cell fate control. Current Opinions in Genetics and Development 37 76-81. (https://doi.org/10.1016/j.gde.2015.12.003)

Zhen CY, Tatavosian R, Huynh TN, Duc HN, Das R, Kokotovic M, Grimm JB, Lavis LD, Lee J, Mejia FJ, et al. 2016 Live-cell singlemolecule tracking reveals co-recognition of H3K27me3 and DNA targets polycomb Cbx7-PRC1 to chromatin. eLife 5 e17667. (https:// doi.org/10.7554/eLife.17667)

Zhu B, Gates LA, Stashi E, Dasgupta S, Gonzales N, Dean A, Dacso CC, York B \& O’Malley BW 2015 Coactivator-dependent oscillation of chromatin accessibility dictates circadian gene amplitude via REVERB loading. Molecular Cell 60 769-783. (https://doi.org/10.1016/j. molcel.2015.10.024)

Zwart W, Koornstra R, Wesseling J, Rutgers E, Linn S \& Carroll JS 2013 A carrier-assisted ChIP-seq method for estrogen receptor-chromatin interactions from breast cancer core needle biopsy samples. BMC Genomics 14 232. (https://doi.org/10.1186/1471-2164-14-232)

Received in final form 29 March 2018

Accepted 24 April 2018

Accepted Preprint published online 24 April 2018 http://ercendocrinology-journals.org https://doi.org/10.1530/ERC-18-0033 (c) 2018 Society for Endocrinology Published by Bioscientifica Ltd. Printed in Great Britain 